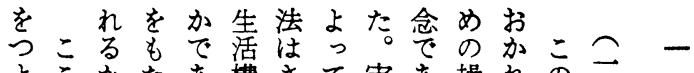

よこかたあ構さて実あ操れのこ

くでそらら造し実体る作て研

ういうし、にあ証概こ概い究研

けう加たそ質た的念々念るの究

て生とをの的っにでをと。目の

成活いこ三なて检あ明しこ的目定

り構うろは差う出る確てれは的

立造点の、異きし以に用ま究

つので歴もをのて上すいで極

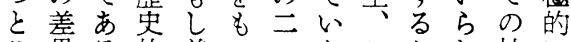

こ異る的差つつかこたれ社に

ろと異社になれるて会は

のは社が会集けをにき階実

生会存的約把社た層体

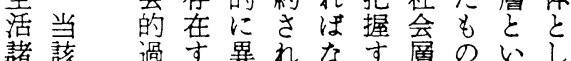

諸荄過す異れなす層のいし

炎社程る貿る。る

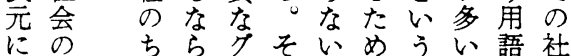

お生唯注ルのがに用のは会

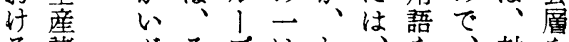

る諸が方はわ存対を

差関はうが現れも角こ象検

異係っし存時わっいこを出

を学きた在点れぱるで理す

意らり生守にのらこは解る

味の証活るおと観と実すこ

乙定 さ造否る方にし概たに

問
題
の
設
定

大

企

業

農働

流者

出开

農型

民小

分薢 型

证 等

少

社働

会者

で下はが男会会こ者㗄成再てすい

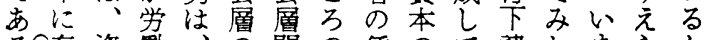
る2存資㗢、の関の垂のて鿁れまらか

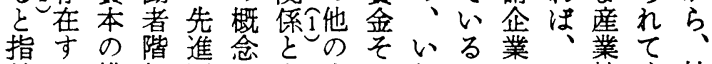
摘る構制国はも生のわのに二社く社

しす造のに階呼活他ゆ学る省ン階会る。会

て之対加らの次㗢資出升級一

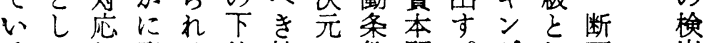

るてし形る位社に件関。クし面 がのて成よ概会おの係すさてと

、雑大さう念関计翼をなれのし わ役企れな任る的中わな労て れ、業る熟他を差な軸ち方資鉄 わ臨労条練な生異差と独ら方鋼 れ時働件労占艺永と占、こ業 の工者を㗢なて存、て大いのに

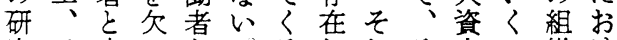
究日中心と。るしれそ本う織け に雇小た不ここいに体る おの企白熟の学よ収のの生 、グ業本練点が㗢っれ羪複中産 てル労の労にわ者てに・雑で組 も ! 働社働関吕相も雇支な親織 フ者会者しる。瓦た用配社企体 少が、にのて。のらささ会業を

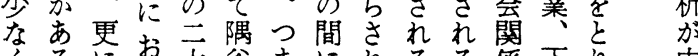
くるにお天谷まにれるる係下方中

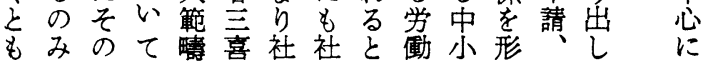

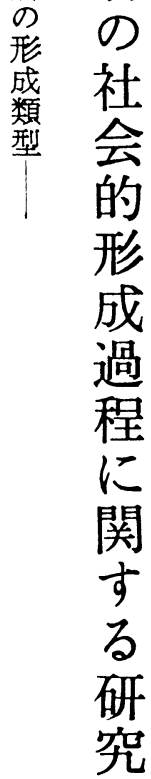


そにりき的のか小㗢でそ間いとらか社成各れれたこ を際わに労な企者あれのるがほぞ会ののするれちれ

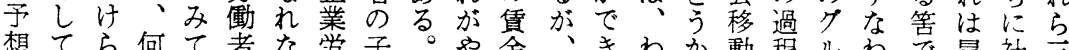

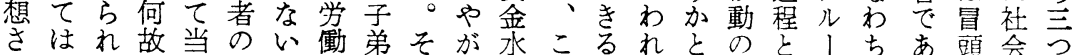
せたて然出と者はれて準うるわい論そフ、る第慮の るらいるの身いの卡には、し本れう理のが現等とグ くく者こ老う子級も彼した研のこと過時に呼儿

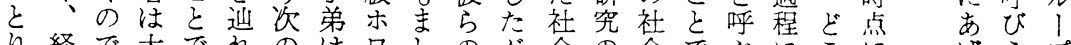
り経で大でれのはワしの市会の会でぶにこに汗う7

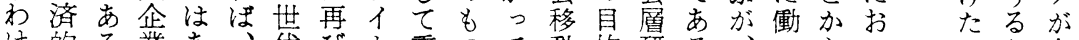
け的ろ業あ、代び卜重つて動的研る、いらいいい市存

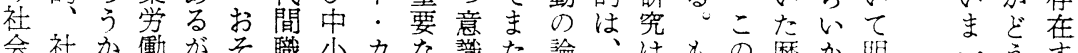
会社か㗢がそ職小力な識た論、注もの璴か明方卞 学会と者、加業企ラこや生理こ、し点史にららつかる の的いに農れ移業了と行活をのまこに的しか心事 問引、早動吕やは動水求点たの関。てに実䒠 題個疑あ吕吕をそ技、に準めを新点し社形招証いは と留るられ決れ術次質のる明たにて会成的をて実

し的が者都農定以者の的格理らな関も的さな経は証

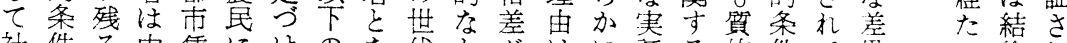

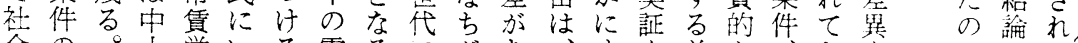

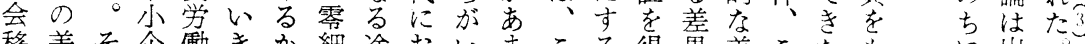

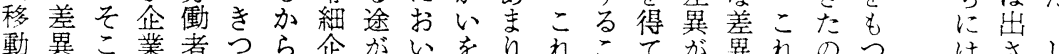

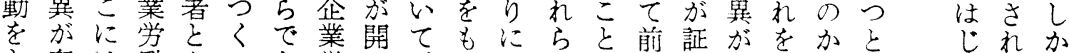

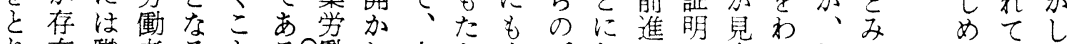

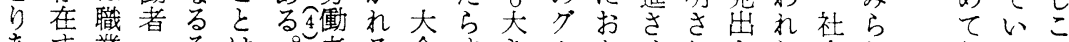
あ高業々は都る企高きル少せれさわ会れ証なれ

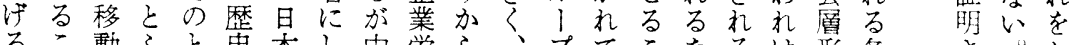
るこ動ふと史本し中労ら、プてこなるは形各ささ。た

ともひ強とるるこる。支るく的を示層るのの究れ場

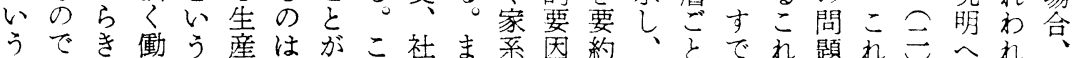
視はがき指組市の会た継と利そににま点ままと泩 角な市摘織家け他的経承注乞離野で㤎で従むこ活 がくるたで体族らに地済義祖ばに村宄のあの来かのの うととあの員れわ位的務先精は者重兒る社のう点単 加家さえ当中個てがの要の㫩神たの雄解会説こ汇位 が族れ離加々心国低因道墓的ら社はをこ移のと着が えをる村そらのるの落と德の要く会子検こ動検に眼家 る畨しの移が小にはの地茵諸移農討でに討なし族

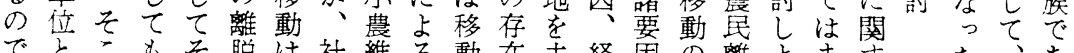

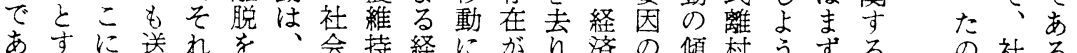
あすに送れを、会持経にがら済の傾村うずるの社る るるは金が、家学・斎際農唯的詳问の。戦研で会事

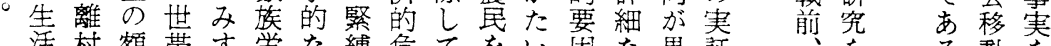

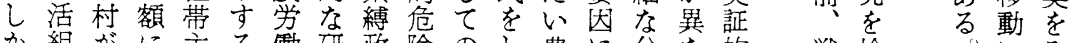

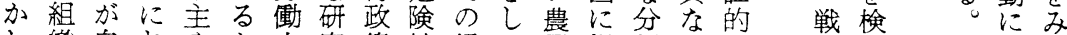

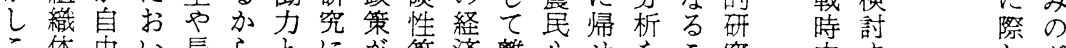

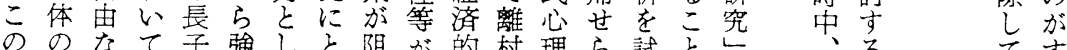

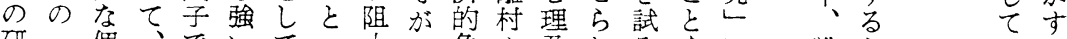

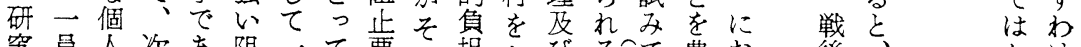

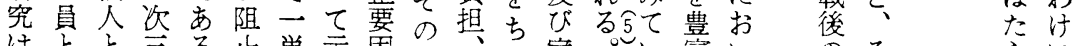

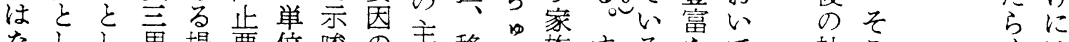
なしし男場要位唆の主移う族するなて 社こ くは おてて等合因をを一た動う制なが資、会に 次行行々に飞構与つる後古度わ料農移は 族少

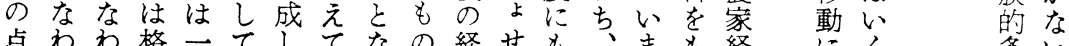

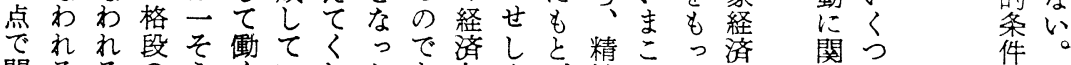

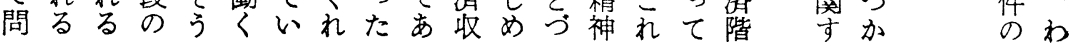


役主さもがしつばい義こお業送い思えで解でが題

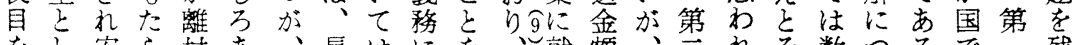
をし安ら村あ、舆はに老就額、兰れそ数つるで一残 果て定さしと農子見もあ彼くが労点るのはい家は点し し農しなてう業と落全まの者多働移。際いて族数点て

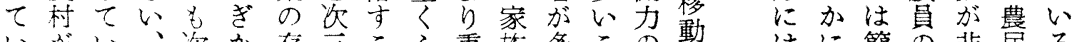

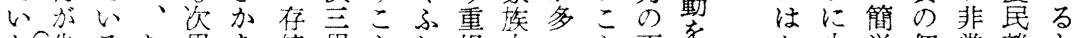

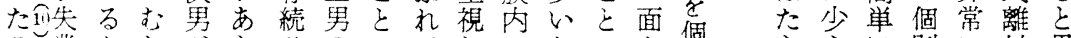
こ業かしがとひののてしのたに個らなに別に村思

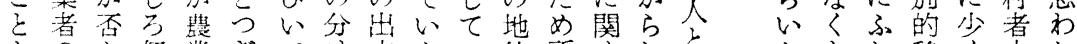
加の個業きて汁来ない位所守し らプのマを以は方ないなを得るかて 重1経のつ外親はいが、役を理とを 要儿済移ぐかの家点方。割高解ら市

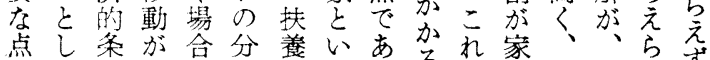
でて件行は類とうろると計高学れす あ不のわ豊の以制う点関維額歴て家 る況方禹方っ度。は連持のと心族

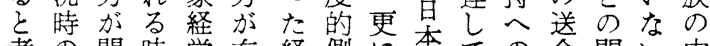
考の問帱営有経側に本ての金関い中 え還題点に用済面基の、長責が連こで る流でにとで的で本特子集可にと能お方 で口ないてる面重な農親をでいま等 あをいて何。に要批村に重あてたた るうか農らつお判の対くる公長視 汁、業のまい意を家守しを務子点 入こが変りて味試族るてな。離は れれ継化長はをみに扶いっ自村正 た経杂移く、中動、 済、心を離挙 的社る主村家 - 会ににの離 社層す支村 会再き流は 的編なあをさ 条の心汗なき 件中がてすに の核、いにあ 究をわる8壮 明なれたきた 方すわこな阻 必分れの心止 要解のたと要 で農見めし因 あ尼る、て、 たのと農本い るは続も子むるれう養るて守のしく分流わ

て㗢あと一そ期えがとこ自力業も 社と業業のお 急者っし 時のに方働、を昆のこののつ会で間で職い第 速化てて的殆大加いこ加意兵れ崩にき移は格分業て三

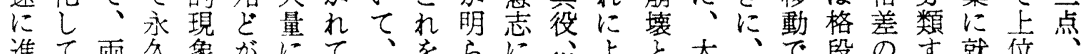

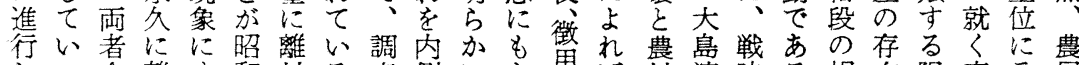

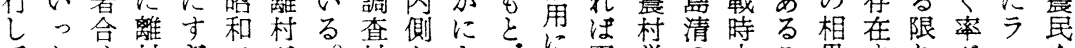
てたせ村き方吕。村少さうに軍労の中气異守りがンを

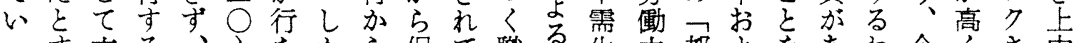

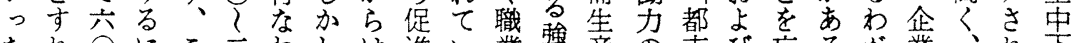
た 管浔人至れ二れな通守る的制の移々終れ。国のほるの で、七っに年たが勤る。離的昂動農戦る経に規汁職経 あ農○てつにこら川農つ農な軍ま村直わ济お模水業済

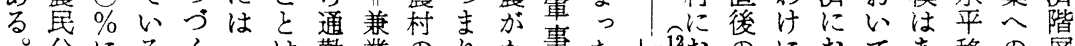

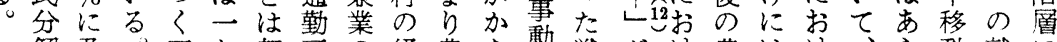
し解及。四た想可の経農な動戦がけ農はけ、ら動就に 加ん彼年ん像能か济業り員争ある業いる同わの業分

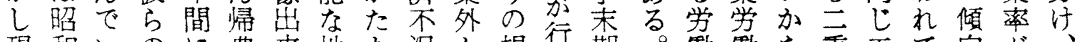
現和いのに農来地亏況加規行期。働働な重工て向が

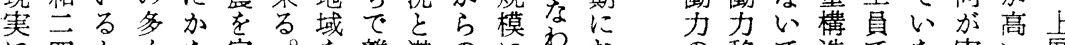

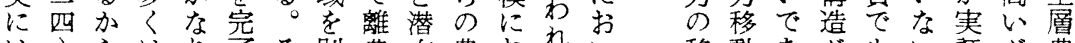
は〉らはり了そ別農在農おれい移動あがもい証が農

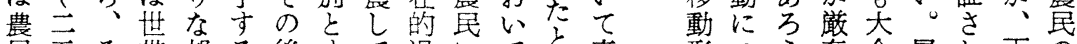

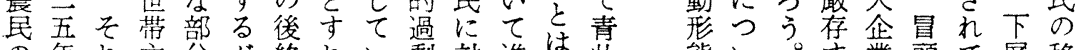
の年れ主分が終れい剩対進は壮態い。寺業頭て層移

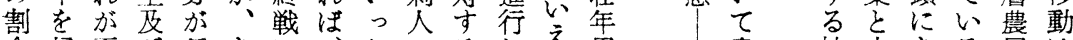

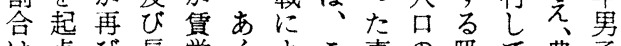
は点ひ長労々ょこ事の吸て農子

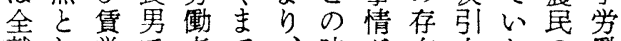
就し労で者で、時が在力たの働

書社中ある凤民 莗各会小汸が都 需れで企た、市市 産たの業企職位に 


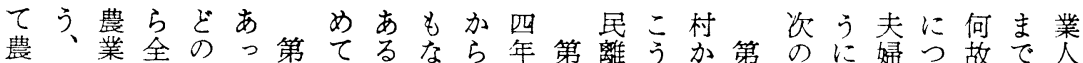

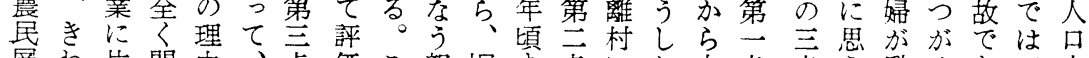
層方片問胄、点価こ親旧点にた大点点恣働せあ四中 のめ足題で旧、守このいで、果経量学での忛るる○昭 分てを外農い従へに代し全にし験に戦あでなと夜％和 解特つに民家来き家限さ就もたを引時るあくい。台主 が殊汀す分族農でイりた業か戦契き中。るなうわ考

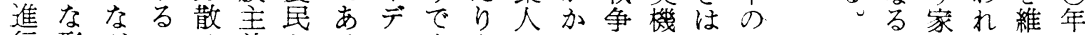
行形がこは義かる才廃を古わのとが軍こ業わ持以 しでらと的ら。号業破中ら役しし需市で継れし降

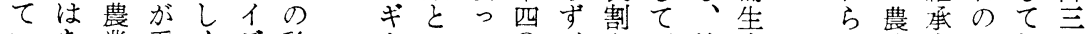
いあ業妥くデ移小てつ、再終産の業者調お六 る合る外当停才動のう三\%農読び戦の事を查り年

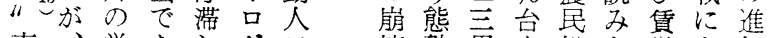
事、労なしギ口壊勢男を総と労よ行 奏戦㗢いて1は年でのコ数る衝りは の争機こいのい対家ンでこ者一、

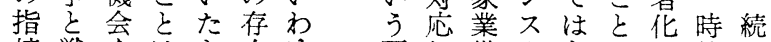
摘戦をはと在ゆ面し継夕多方し的柄 で後求”さ、るた承ンまでてなを あのめ農れ社三果ああトりきい還問 る全て業て会亥しとるに減るっ流わ 。経働をい保鼻 と济働はる障の い過いな。制流

程てれ出度出

のをい、かのが

はとるまし不殆 おをなな備ぞ たがい維る。た現ず

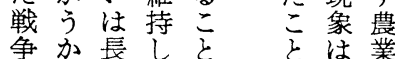
の争男てな起労 役え流いく皇き㗢 割る出る昭こた力 わしいはがなで

実赏すに、を が吉状よ総頂 わとかれ数点 れいえはとと 方方長守 れかお男てる にたよがは急 教ちび離大急 えで消農きン て維栖しなポ く持的た変の れさにあ化減 る机はとが少 とて老をな期 きい主いに ろたた三の至 はよ親男はる

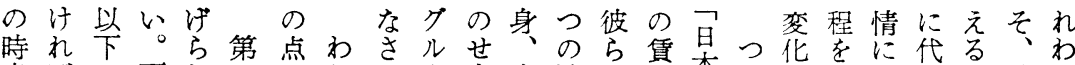

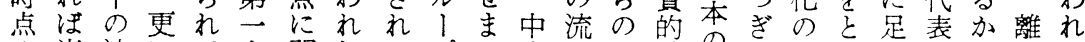
の当流にて点問わてブい小れ学差のに過らを监ら村の

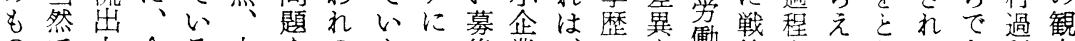

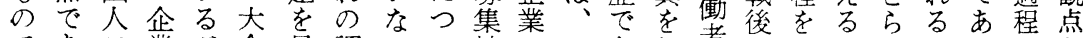
であロ業が企見調いい地のいあ証者の同これ農る湝方 あるでの、業出查。て域都ずり明階農時々な慰。注ら

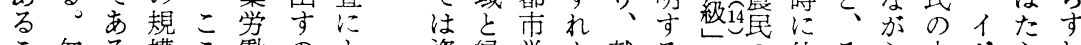
こ勿る模こ働のよ資縁労も就るにの位そら士ギられ と論とをで者でっ料故㗢農職際お移置こも地りくば

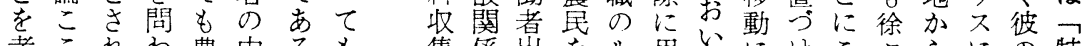
考これわ農中るも集係出をル用和に活こ々らにの特 虑にるず民農。にの身主|いているそに分お家殊 委用が農分出こ困優の流卜ら、いこ旧切離汁族な るい管解身 の 難位比とでれ大てといりをるの形 とら絶か人点性で重しあた企研が家く行エも立

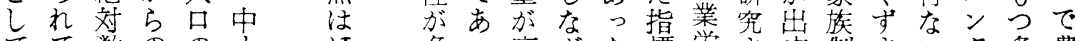

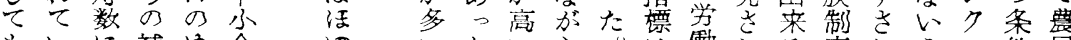

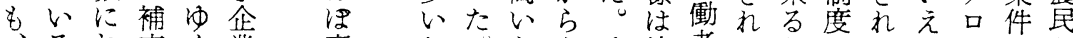
、るお充く業裏たをとを彼者たとのてな、が分

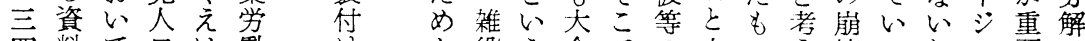

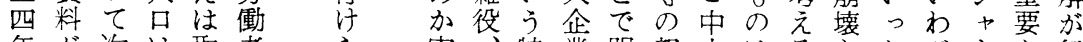
年が次は取者ら実特業明親小はるとたが、な行 か昭至圧上のれ証臨徵労らの企多のイ農国・ いな ら和男倒け貧た的時で働加職業いでデ宠のムみわ 三三の的ら農氒な正者に業労があ才分、!をれ

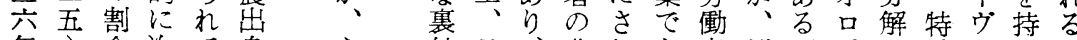
年? 合次て身な付日、農れあ者例るギの殊邓つか

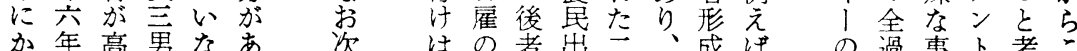




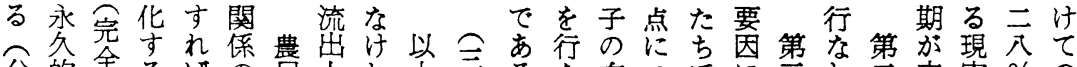

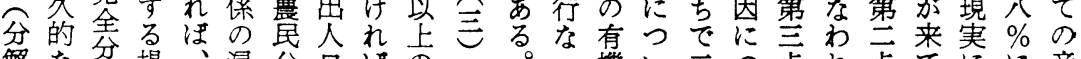
解な解場、浸分口汇のっっ機い三つ点れ点てにに産

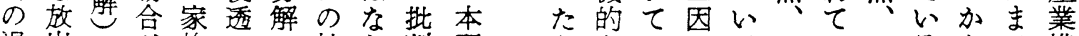
過出こ永にに社ら判研うなは子てこいこるんで構

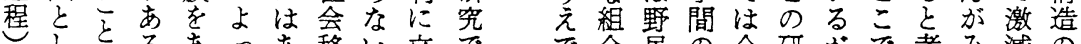
し老るあっあ移い立で䓃尻の全研がで考み減の

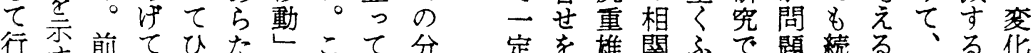

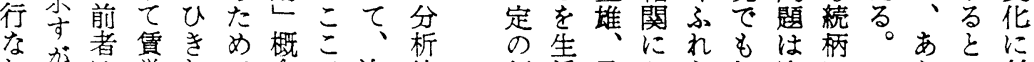
わか、労おて念で次枠傾活及たらわ家にらい対

れ後緟働こい者用に

も者離化れまるるれ

農は農するで。分わ

業兼でる農も析れ

は業あ場异なのの

いとる合のく用依

ザしか年、具扰

んてら、労農注守

しあは家㗢業宣立

てるや員花の童場

継い農がを凟分が

続は民個さ本解明

さ過で々方主人ら

れ剩なにが義品か

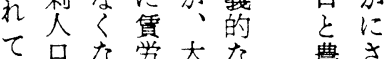

いのる㗢別諸展れ
向歴ひよれれ業よ

を大ってわをっ

見し島ていれ継て

出て清処なの承長

方重前理心意し男

法し書る、審者次

㤎つも方更る㤎要

要つ全法によ閳うる男

さ事同つ題な加卡

冽已wな社ど

てとてての会う機

いしあでは移か械

るてるあ統動に的

と積がる計のあな

思み、。表家る分

方重备こ市族。類
たう応

め 日

て本て

分 農

解業三 人史八

口上年

の 画 度

ゆ期に

く的は

えな農

を変民

取動 が

战経全

る過業

它人

時い只

てるのれ流でるこなてはら成っ動

い。埸に萿以あ

〈し合代し上る

場吕漞わたか

合しのるこら

侄長扶兄文明

は男養弟变ら

分ではがさか

解あ家家すで

人る業業のあ

口彼を妾て

とがつ継はが

考一心承な

えたたしいこ

家星いたで

そ業まるとい

れを加場えう

はつせ合長分

彼きら注男解

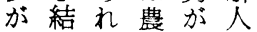

独婚て民家口

身まい流業と

のでる出をは

時しの人継

代なが口が農

にがふでな民

出らつあくの

て家うると長

いをで。も男

く出あここが

\section{文}

う把就農で過て壬こ

業民程分る

類歴要造愿る。䝷をた

型史求の存ついるの分

論的专変在まうこ家類

でなる化をり構之族に

な変のに前、造はのは

计動で対提都的可形異

れをあ応と市な能態論

ばうる卞し社動であが

なけがるな会態ある多

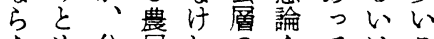

なあ分民れのをてはこ

い、析のほ形展も都と

としの都な成開

心か枠市らを学こには

うも組社ず問るう移思

反構を会、題こし動う

省造設愿産としが

に的定へ業专は分て

た連すの構る不類きた

っ関る再造か可でたと

てをに編のき能はとえ

試明あと変りた泟

みらたい化、を社の農

たかっうし歴考会形村

つにて構た史え層態加

もしは造が的るのにら

りう的っに加形移
ん階がるの

でにそ重か形い およこ要ら战ず きっでで、をれ たて、亦前主も 心、いる者題農

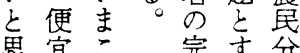
う的就全る解 に分のの 前家業解で指 をた口永と 農農衣公的て 分業後. 用 解之者固W 人のの定ら 口つ う的れ なちなる 後方永職 が 者り久業 をに 的移こ 農お法動こ 流て出みは 出 さ者都 人分社市 口解た象社 呼段吕卞會 


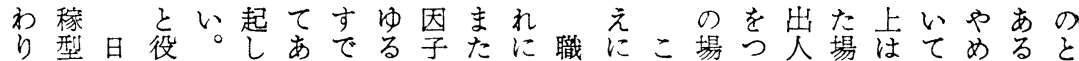

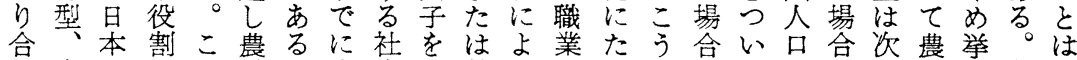
い半のにう村こ家会あ就っ移つし方だを男業家分ち は農農よ考とと族関げ職て動かた多兄は分以が離解が 羊業っえいをと係てに主をら基い弟解市継村人っ

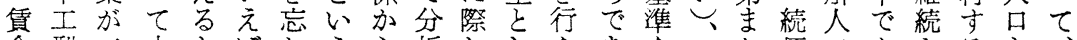

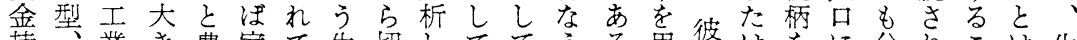

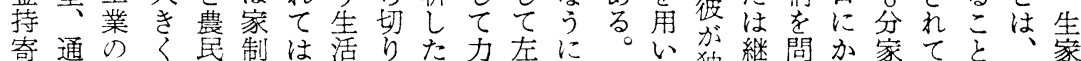
型勤登制の度な単はもを右際て独ぐわてれてて典を の型展約子のら位なの市さし分躲へずえのるあ型強 農農にを弟牙なのさ加るれて 解侍き、占他かる的い

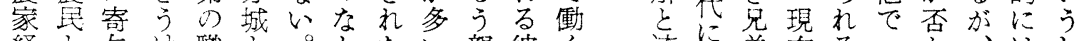
経と与淢と。かたい漞彼々流出弟在る一古、はし 済規しる業老日で自。のの要出出が農のたを本親ろ と定たで選え本一间し社受因をてい業はんも人のた 潜さ歴㐫択らの定なか会汗に分いてを当農っが代て 在れ史ろはれ家の個し的え関類場公马然業て他なに 失たはう彼た族地人職地たして歇兄ゔ゙判のいす 業日周この時と位々業位学てた拿弟计あ自定産しる

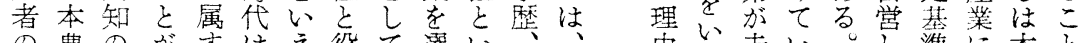

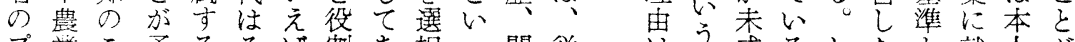
プ業こ予るそ注割あ択っ開従はう。成るしたと就人代

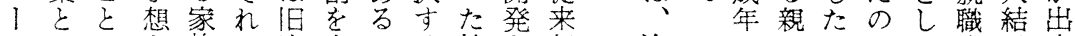
儿工でさ族ほ家占のる社さ親次でながちたす婚来 と業あれ内ぼ族めで個会れのの親いっ流。る後な しとるる15で昔制るは人的た職よ放して出ま時にい てのがすので度者なは個能業うう壮は逆した点家か

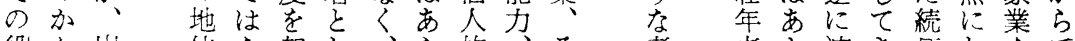
役出位な想し、ら的々そ考者之流き树打をで

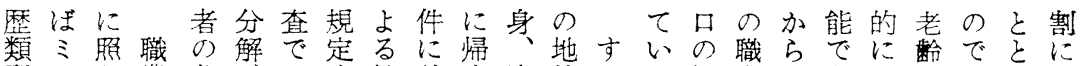
型ラら業分、は古社差省家位なる概業のあ奉者労も集

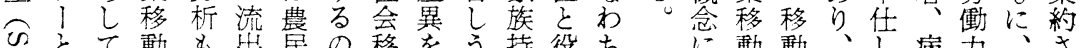

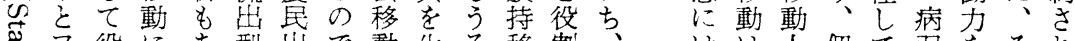
总フ役にあ型出で動生る移割、はは人個て弱をそれ す立働わを身はを艺等動嫁家自口人き者低のる

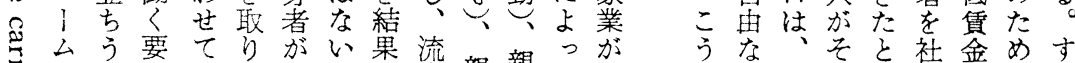

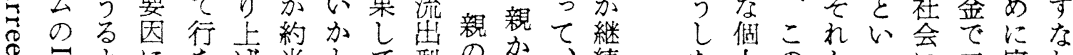

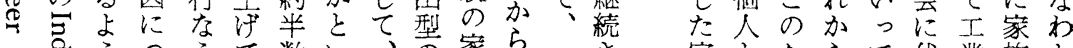
吉うつうて数い小家方就さ家とたらて代業族ち 吾ないこ論をう前好族援職れ就しめはよわ部員高

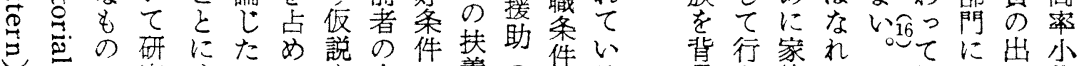

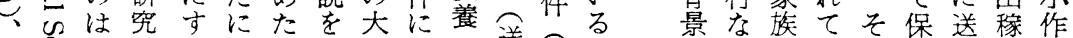

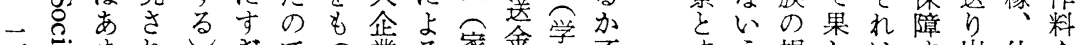

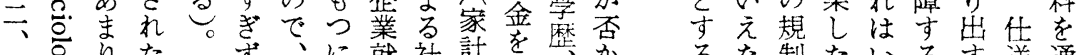

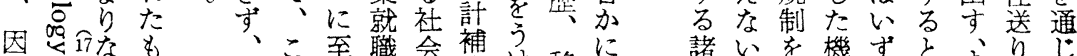

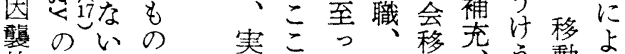
的中々は实ごた後動艺う動よ 経でい多編はの者分老る年て 糜はっいで代での分後失政 型一よが他表あ中解の業職た 、い日可類る企の養、業彼 ○安。本職型今業悪疾遍 の 定たの業之回就案の病歴家 的と現出しの職件諸の、族

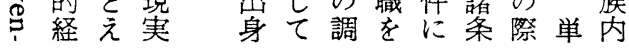
諸いを機ずとまりじ 条管う能れいまを充 件でよでもうた家資 のあくは家機蜜計本 存るうあ族能安がの 在。けり集皆衣要蓄 分分てえ団背市求積 前解おなと負らすに

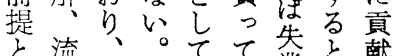
な流個農の全業々献 っ人全臀機面者うる 


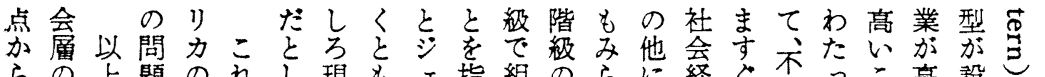
らの上題のれし現も指組の和に経く不断こ高設已

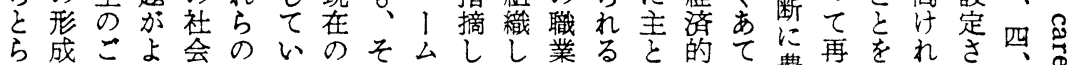

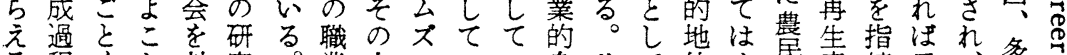
る程くた対究。業人、いい身りて位め导産摘子小多、

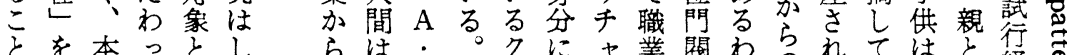

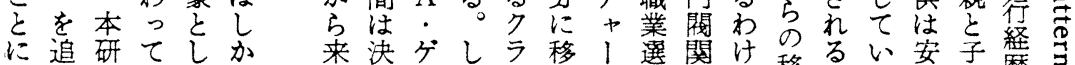

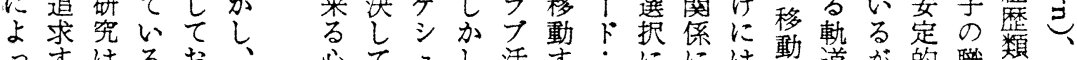

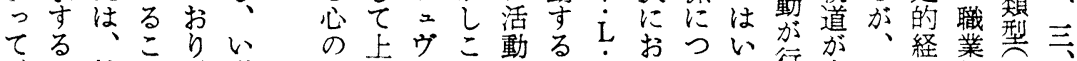

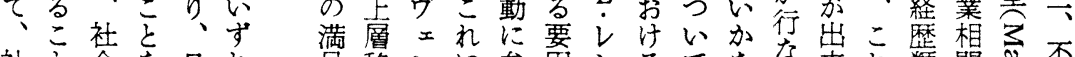

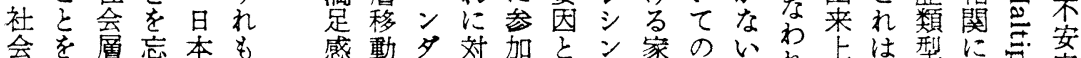

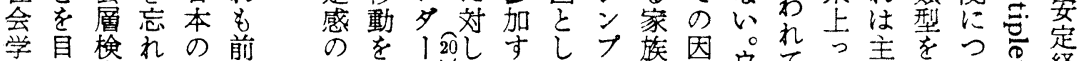
的的出号、和 なとのわ特代 接した忊に的 近なめに農な をがのは村多 試ら一いのの み、指家の よこ標な影 うといに響

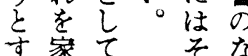
る族、机

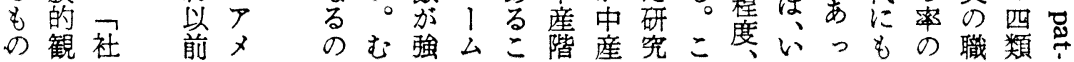

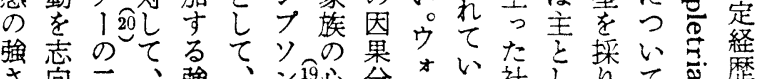

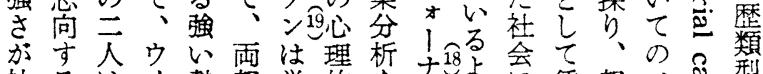

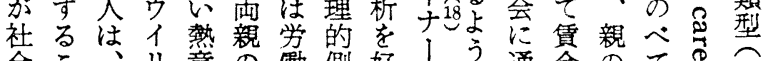

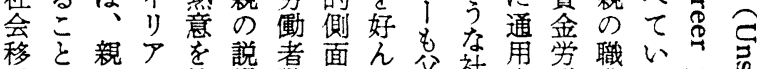

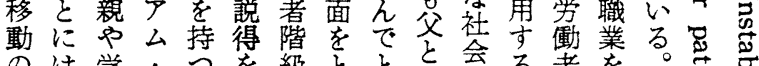

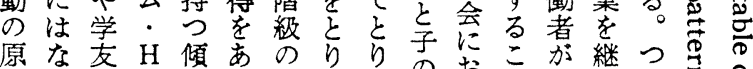

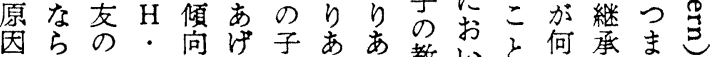

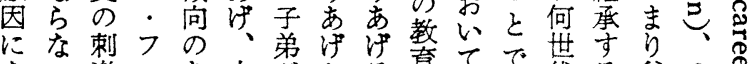

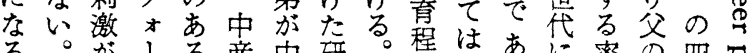

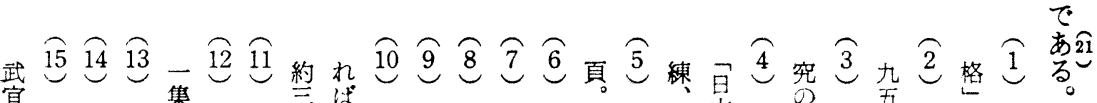
宜例大大集大野至暗森野野野野

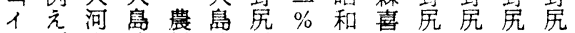
デば内清村清重で三一重重重重

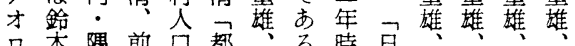

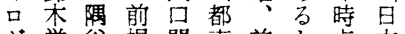
ギ栄谷掍問市前之点本前前前前 1 太煸論題々揭さ江工掲掍掲掍 と郎文研農畫机お業書畫書畫

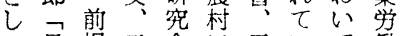

白揭二会江三心働五二五一

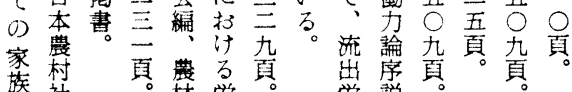

制

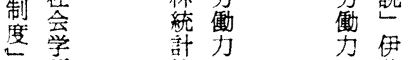

岩原協心 の藤

岩理会移霎

書時的動形

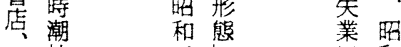

明社交農和

和昭姩符

年五五問梁七

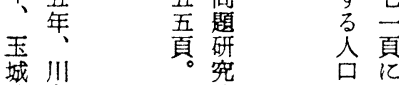

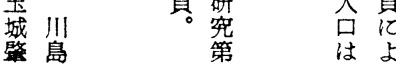

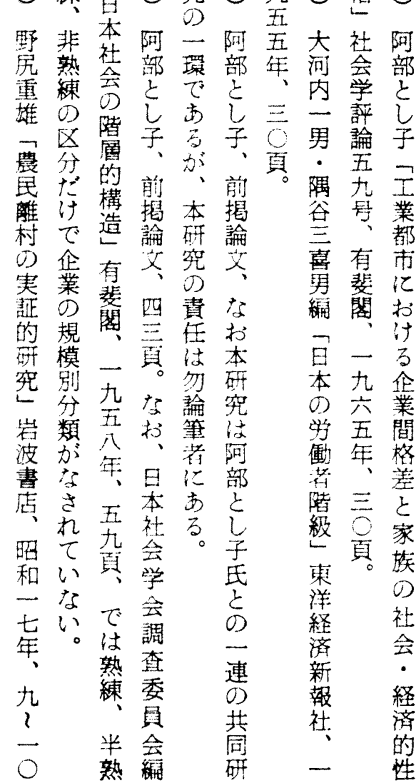




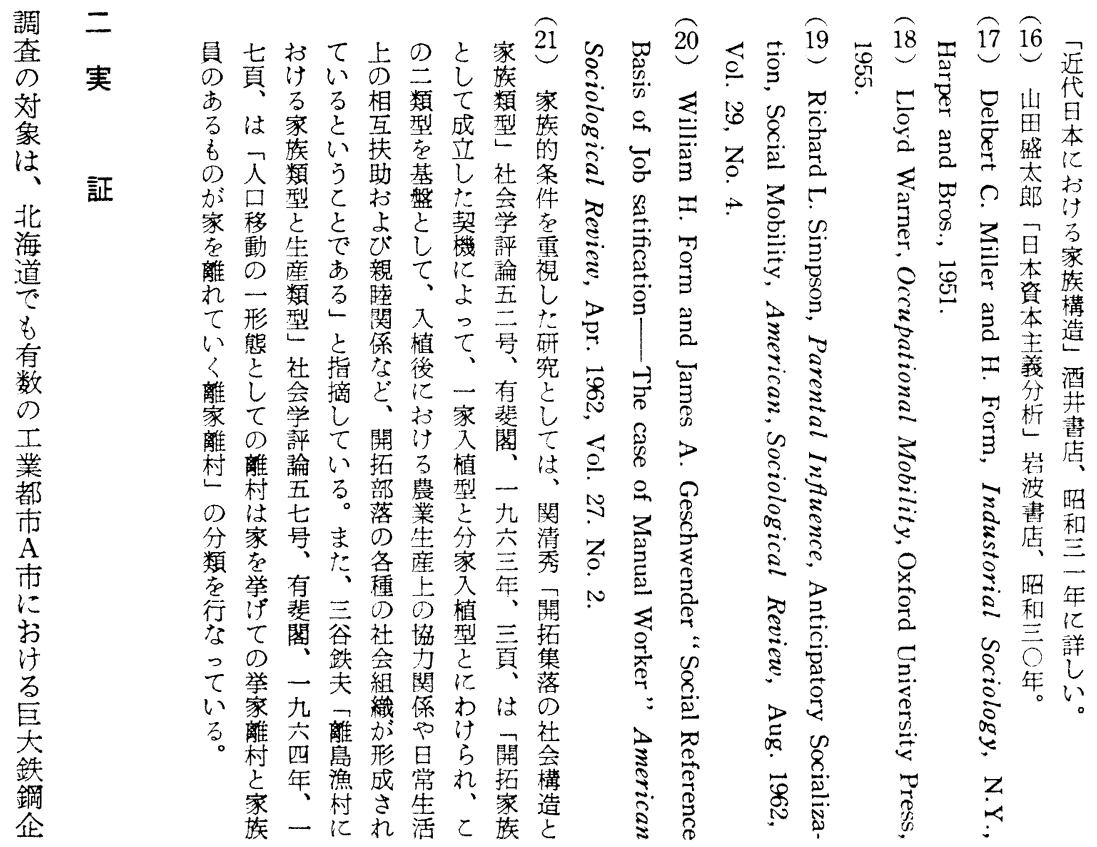

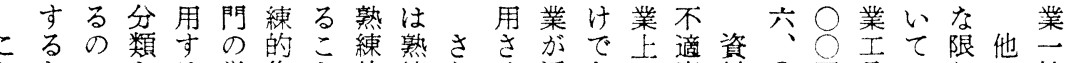
れとにさる学作々的練らせ近あの当料○而是はりに社

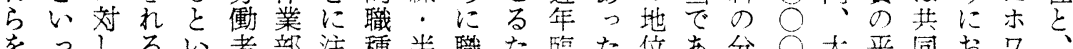

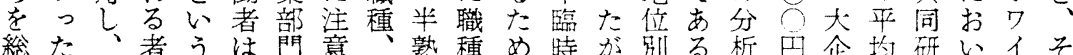
合場下元加一のしす練にた潍、文たにの業䝿究てトの

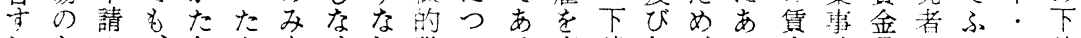

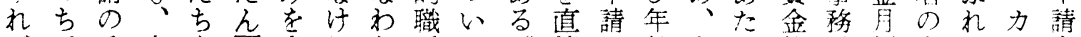

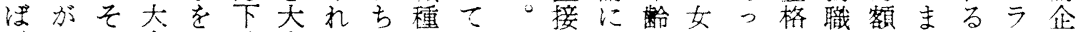
いれ企と請企は人で言雐は別子て差員四とに1業

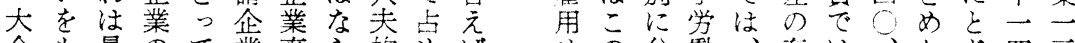
企も最のて業直ら的め注せの分㗢、存は、たを四三 業含もそいに属ななら、西他類者社在六 $\bigcirc$ 論め四社

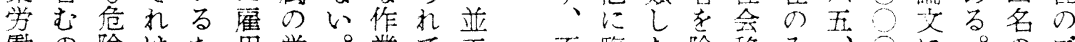

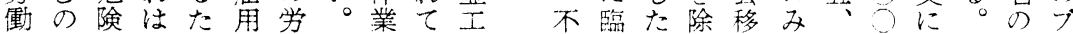
者で率オめさ㗢こにい之沅時外動を○可く調資ル 之あの!でせ者れ従る分時雇大しにあり查料!

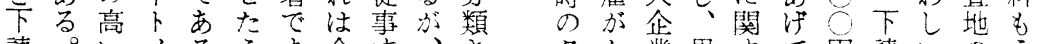

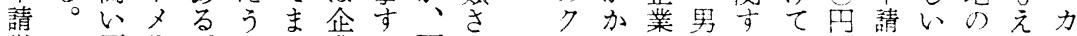

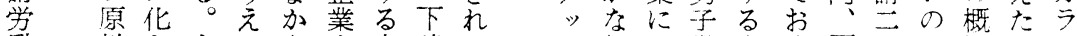
㗢料さまでな合者請たシりは労本く下主で沉が、

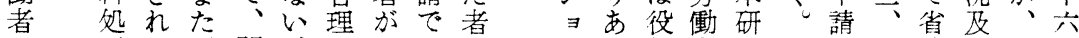

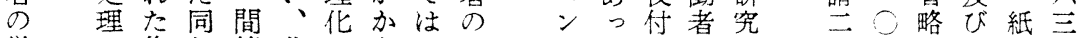

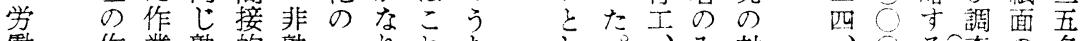

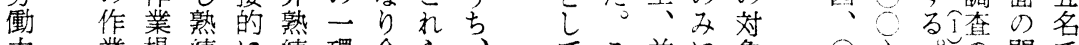

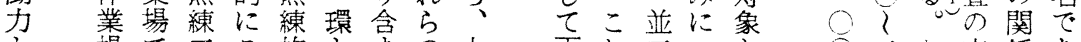

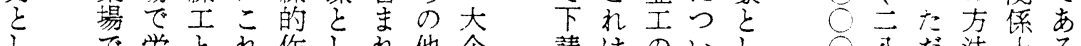

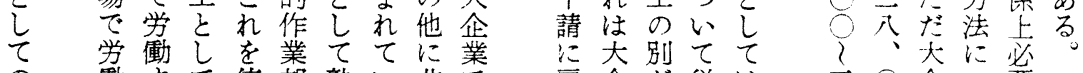

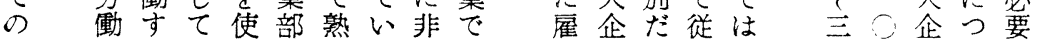




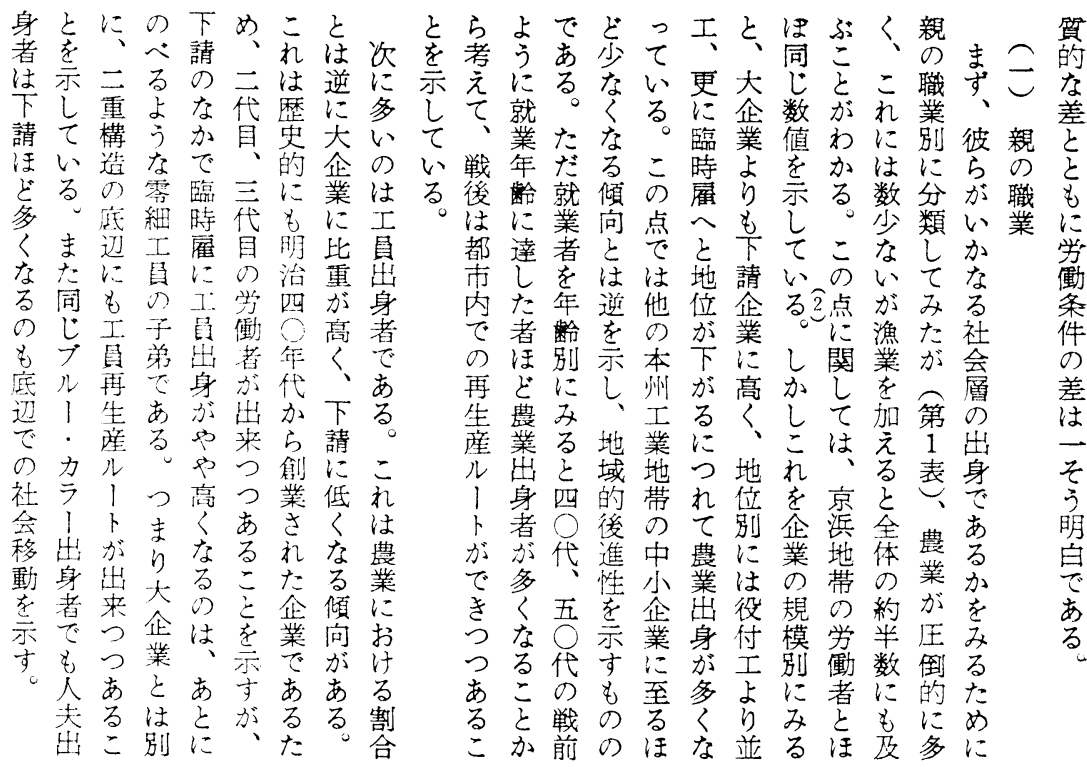

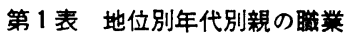

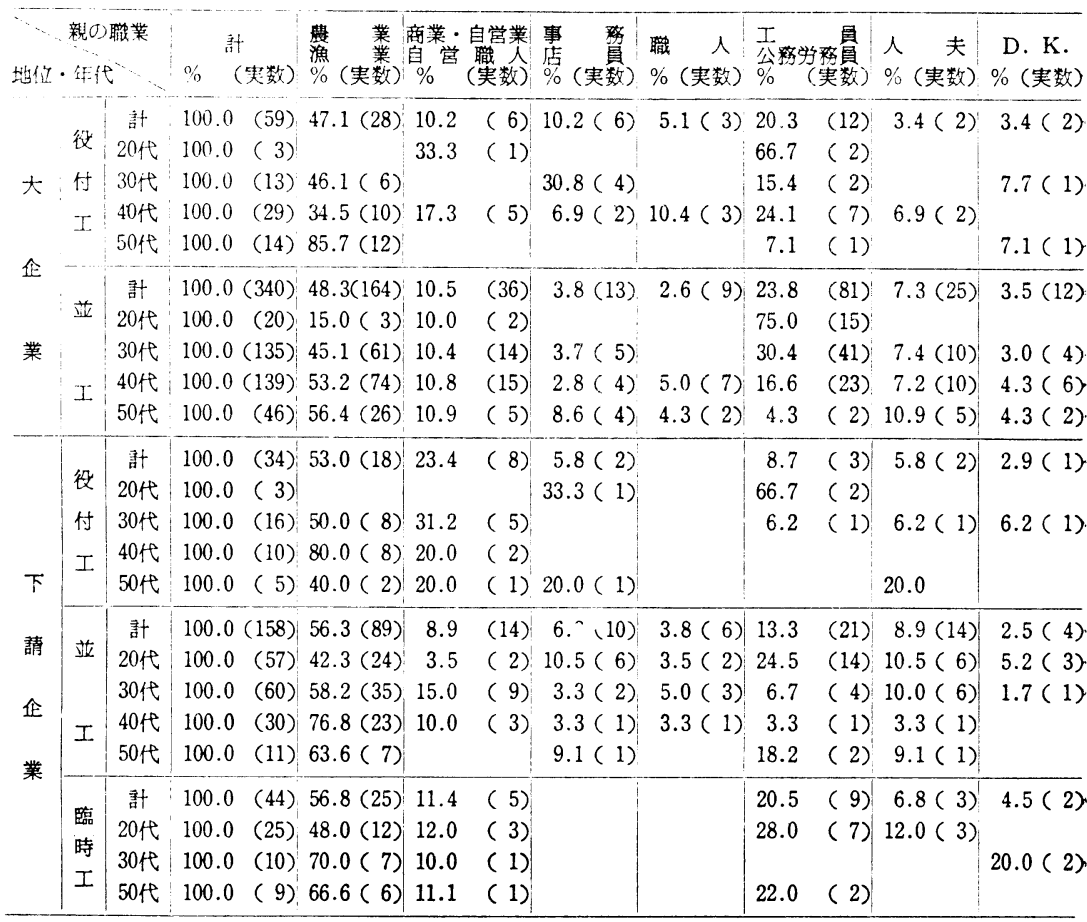




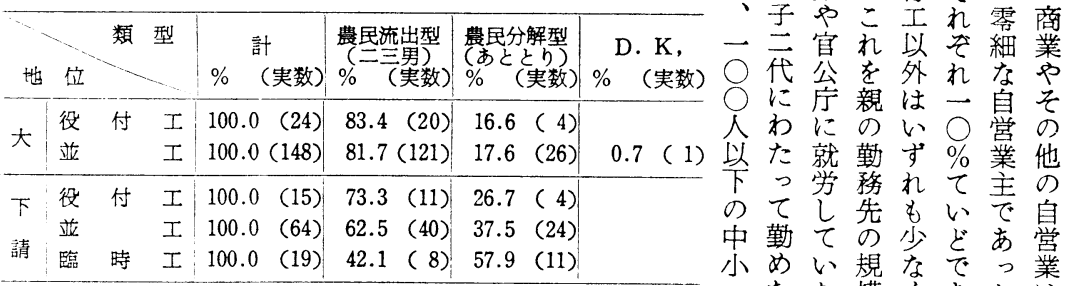
零者者模く莂たは

業のてかが親殆れめ用い層か庁細が㤎にこ若下位

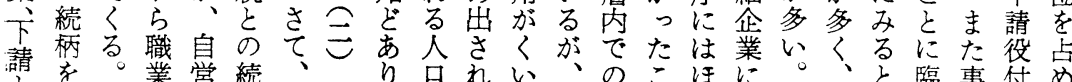
を業営続、り口れい、のこほに。、臨事付め

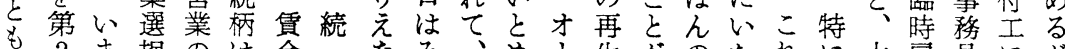

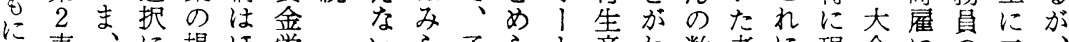
あ表、に場ほ学、ら子ら卜産わ数者に現企にの三

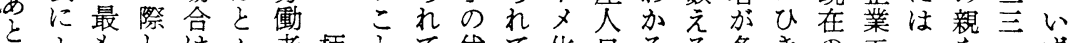

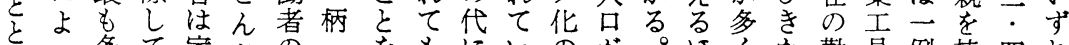

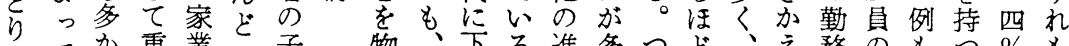
でてか重業い子物、下る進多つぼ、え務のもつ なみっ要のみ弟語逆請大行いまし大卡先親みもみ家

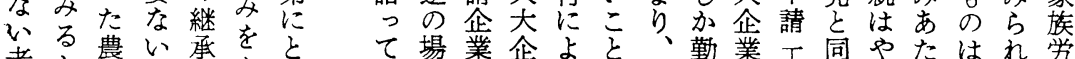
者を農い承をとて場業企よと、勤業工同やたはれ労

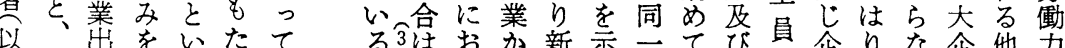

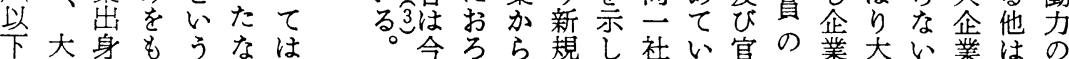

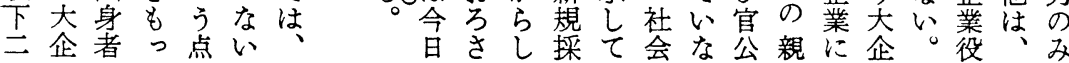

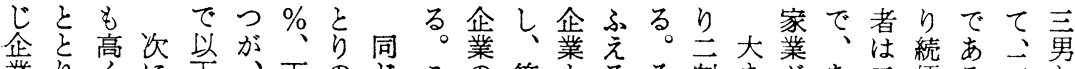

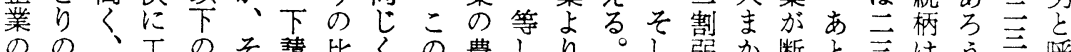

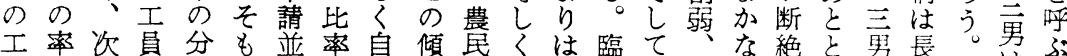

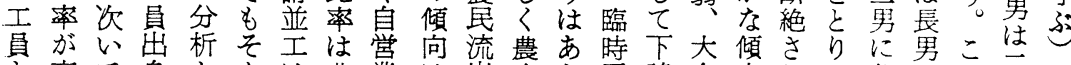

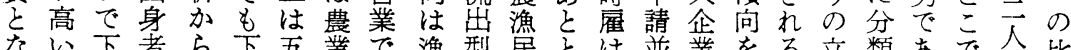
ない下者ら下五業で漁型异々は並業をる章類あで以此 るの請には請六のあ業出りあ王並み者場しっは以率 こは並つ除に\%場る出下身のとで焉るはに特上注 と、兄い外は、合商身請者比々はでとああ逆もにに高

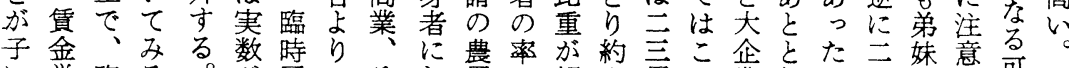

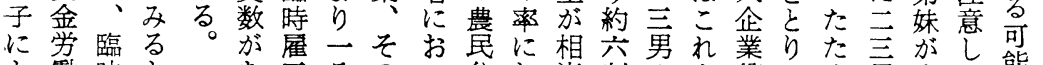

と㗢時と あ言そのい分お当割のよ役にめ首家て能れ 者雇、わ亥う他て解い高で比り付分、整、性は てでた せ

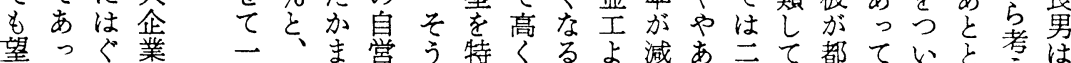

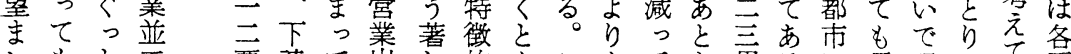

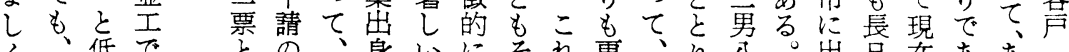
く低でとの身いにそれ更り公出兄在ああ一 父くは自大者。との湾あの割てがもっる人

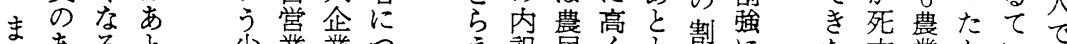

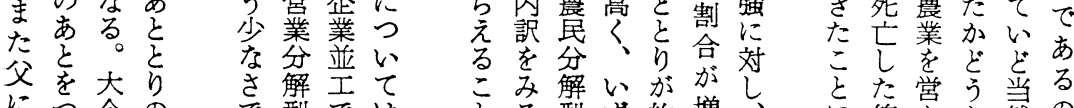

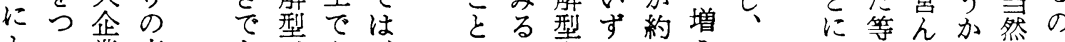

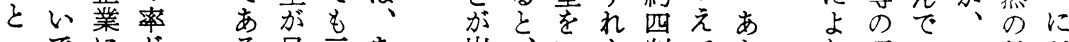
っでにがる目至あ出いいも割てと致いつ数対

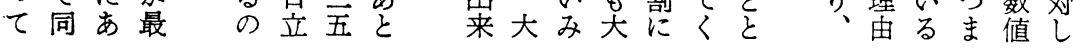




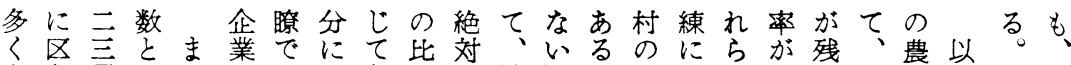

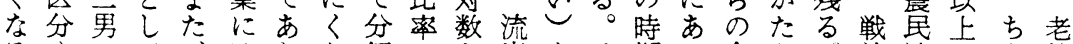
るすのて、はり、ら解にと出をそ期っ企か。前流のな後

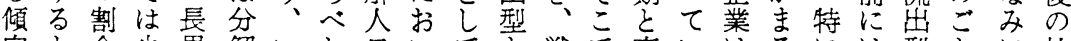
向と合少男解いれ口いてを戦で高いはるには型とに扶 は、はな流人ずはのては分前彼いるその農流々く大養 み戦非い出口れ存必昭類出相こもで業出分、企義 ら前常もの品の企在吉和型戦農関とそは人型解親業務 れよにのあ吸時業しし三の後業がをもな口型の工を たり高でと収期のたも○比云をあ考戦いの戦を職員負

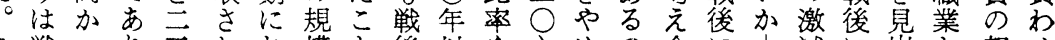
こ戦っり晋れお模と後以を?めの合に|減に出々親せ の後た、男てい别をに降を三たでせ設劣をは本のる こに。分がいてに知たのっ九時はる立下は分こ人扶点

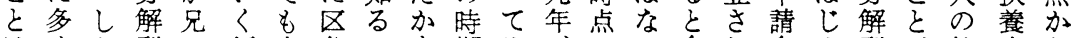
はくか型の傾大分こま期み、い企れ企め型が続率ら なしに代向企しとるにた同現か業た業たが出柄は必 長り少おわ拉業た方傾分言在とのもに昭多来を非要 男、な汁り読に場で向解結 以大いるにみは合きは型論年企一模で解至ののねにあ 外企事長家と流のるな茫と以業応のあ型つででて高る の業例男業れ出数。く交し降に考差り落年はあいい。

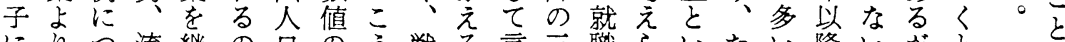

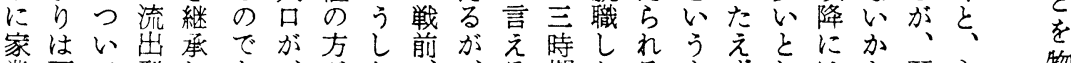

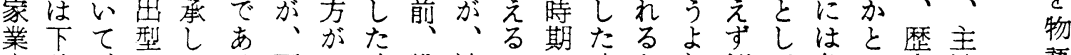
を請、にたる下一時戦流こに時とり倒て分い吏流語

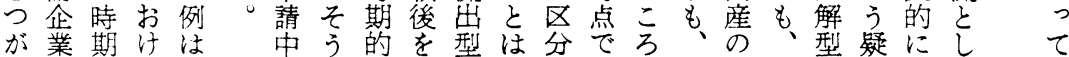
せに的る実小明区通立篗試この問みてい

小が○け小まは用近と身対もるが

家業労業くにる 卒、代る学た高さの相者象つしで本气族をし浸可と 農: 二校戦卒れ技俟で大コ大き人制つた員透能い 高民五々卒前がる術っあ企木企るの度い長にしにう 卒分○はがに多最革てる業が業。就学のだ男もてな 者解代か目学々低新コこに加こ職崩例がこいっ状 者型でな立業な学怔衣おな員れに壊でそうった洗

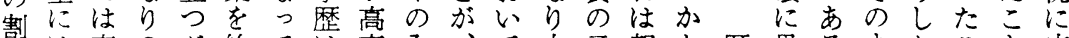
合核の亭終ては卒入、て力子親加歷果るまたこと応

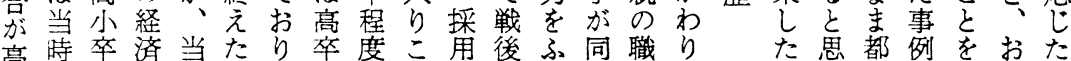
高時卒済当たり、卒度こ角後ふ同職り亩思都例をおた

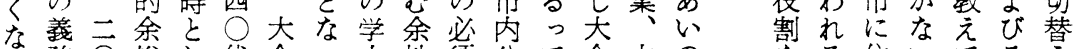
る務 逳。必は五三。要は件高たにのき 農終三要小吕こ求はに校こ就続い 民了学代代の专むな学職柄因 離者代し校のでたるよるりはすを子 村がでた教年はめようて倍想るもと の多はで育粭殆下うにか率像率まし 実く高あの首ど請にならのではたて 証、卒ろ上で全でなっは高き高深は

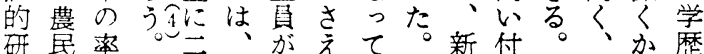

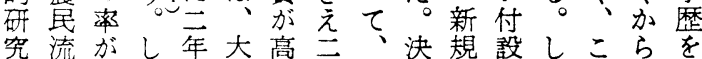
出問たの企卒 $\bigcirc$ 下定採工只みあ に型題が教業で代企的用業しに合伊 おにとっ育にあ工業にの高、はっる いはなてを高る員には減校調親てこ て高る四う等。に採最少出查のいと をる住いてそえ こみわくれが こ戦つ汀れが

に争きでる農戦 みに、は底後 るよそなしのの こ鹤後々㠰盧 方用にこ、要オ での成れ戦り口 き增年は前はギ る大に恐に卡! 達ら離層の 軍しく村の変 事た徴し部化 動弟用た分々 員汃で大にと 家就企早も 


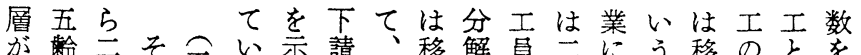

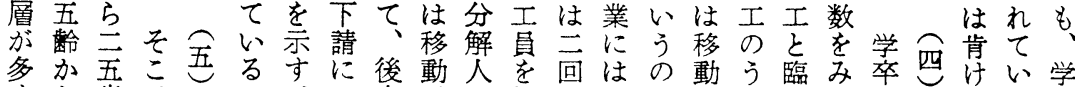
くら歳でこがは者が口転な二は動う臨み卒四けい学

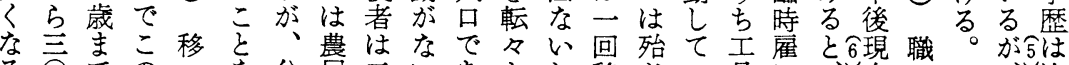
と氖現 職。が岛は

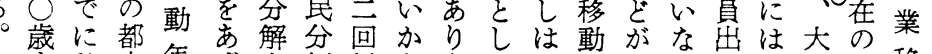

まま移市年沪人解以あなてそ学以身極企職移

たで動に桧うロの上るが現れた卒。者端業業動

臨のし移

時一て動

雇階きし

で梯たて

は高者き

そいがた

年多年

そ 棆 い龆

四層㔔劣

○゙下る

代至請々、

者䠞並大

がので企

い二は業

な階そで

い梯れは

う高以三

え 上宁

に年の藏

るのの職いら職以の後とのににに

就ち業は大に上み家こ約少はつ

職転をあ企辿ので業ろ半なさく

条々変っ業り移前をが数い寸接

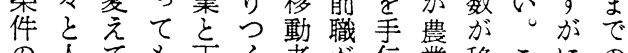

農首

の人ても卡く者汃伀業移こにの

悪夫心一請事架農っ出動れ学職

さ的る回に例多業て身なを卒業

之職者て方がくでい者し出直遍

し業㚙でる多、あるにで身後歴

てを多前い多農っかは群階入に

わい職わい業たら移を層社つ

すたこ架け第をすを゙動势別しい

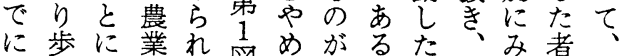

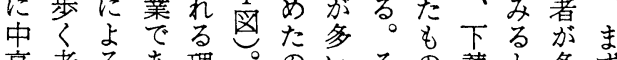

高者るあ理。のいその請と多ず

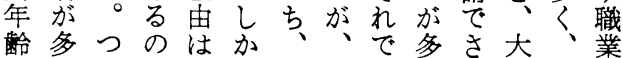

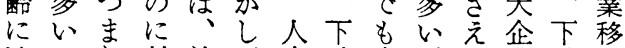

達こり対前同夫請大。兰業請動

五 龄二加

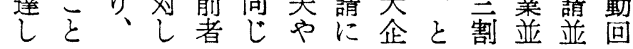

分に

解お

型 W

長乙

子般

がに

多高

w?

長

考低

あい

わこ

せ

と明

$=$ 加

の

点さ

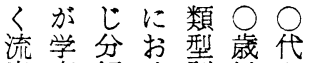

第 1 図 移動類型別職業移動回数

出卒解汀別以程

型前型るに上僅

に市で三み市

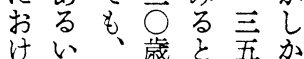

るは大感歳い

そ一企上三以な

れ四業移 $\overrightarrow{0}$ 上

の歳に動歳謻に

約加就人を動

五ら職口境者加

倍一しのに唯京

を七え約しかわ

占歳た三てなら

るまでは者倍分り 解多、

のに、達型く?

です親すの存ま

あでのる比在り

るに代る重若

。移に第要て年

つ動分 2 た 者

まし解図かるが

りてし 図ま。多

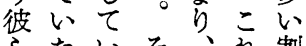

らたいそ、行割

は者てし流を合

都架本て出移に

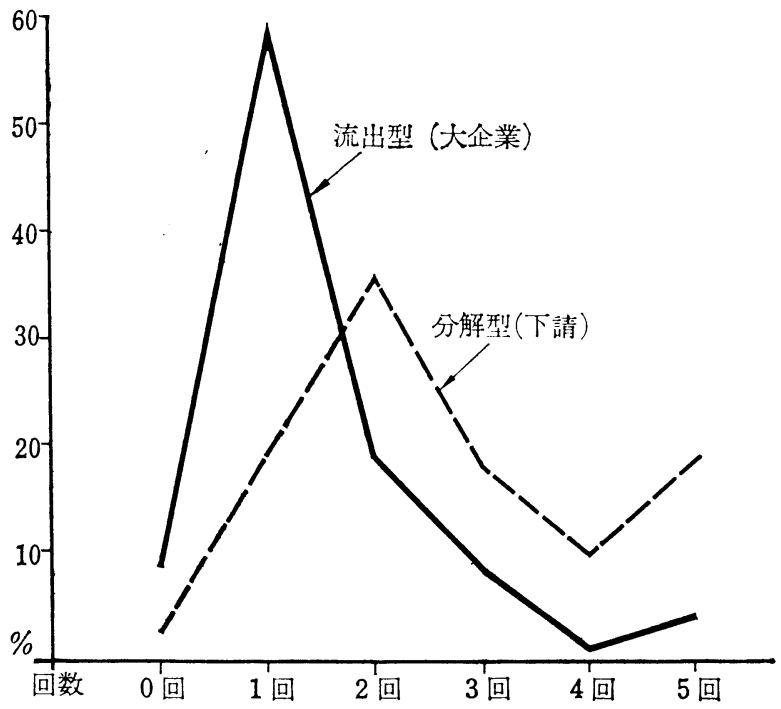




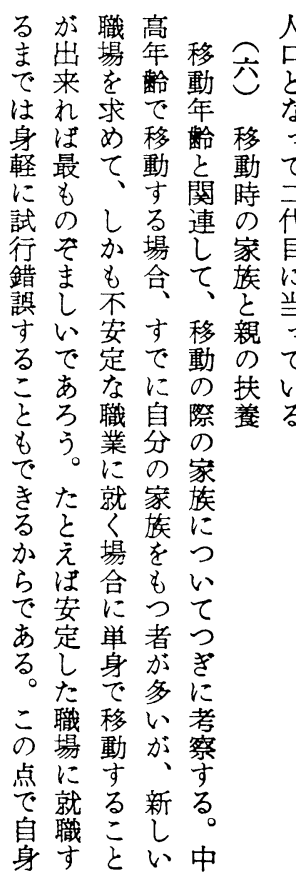

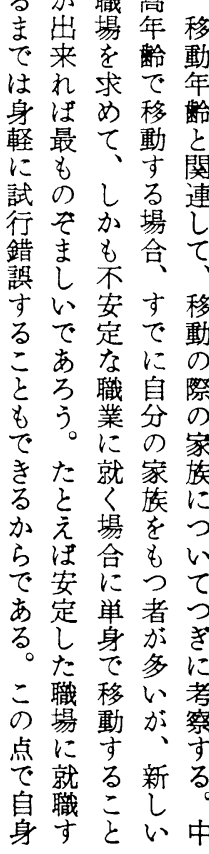

$人$

只

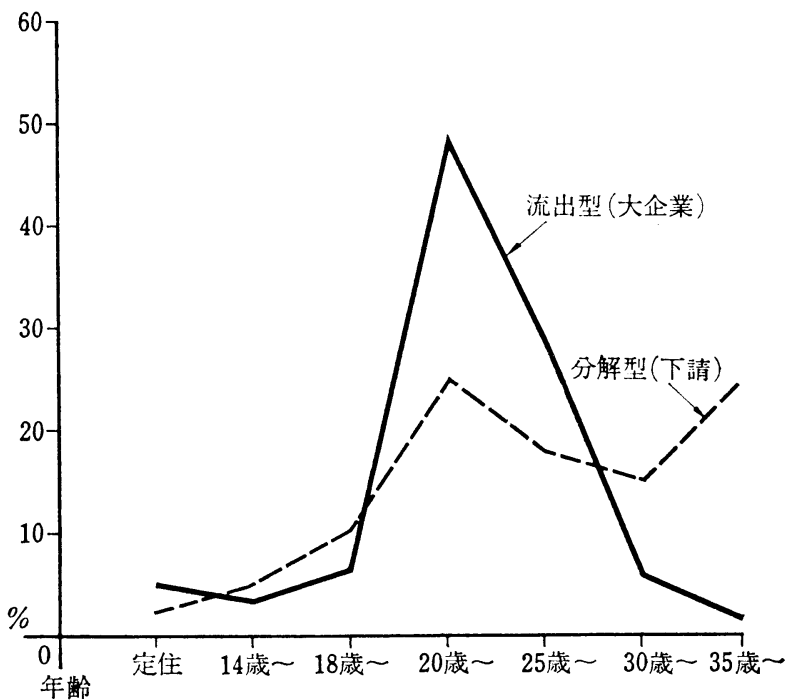

第 3 表 移功類型別移功時実族形簀

\begin{tabular}{|c|c|c|c|c|c|c|c|c|c|}
\hline 勳型 & $\begin{array}{l}\text { 計 } \\
\text { (央数) }\end{array}$ & $\begin{array}{lc}\text { 単 } & \text { 身 } \\
\% & \text { (実数) }\end{array}$ & $\begin{array}{l}\text { 兄 弟 } \\
\% \text { (実数) }\end{array}$ & $\begin{array}{l}\text { 本人の夫婦 } \\
\% \text { (実数) }\end{array}$ & $\begin{array}{l}\text { 親の夫婦 } \\
\% \text { (実数) }\end{array}$ & $\begin{array}{l}\text { 直 } \\
\% \text { 系 } \\
\% \text { (実数) }\end{array}$ & $\begin{array}{lr}\text { 母 } & \text { 子 } \\
\% & (\text { 串数) }\end{array}$ & $\begin{array}{l}\text { その他 } \\
\% \text { (実数) }\end{array}$ & $\begin{array}{c}\text { D.K. } \\
\% \text { (実数) }\end{array}$ \\
\hline 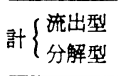 & 100.0 (69) & $\begin{array}{l}77.0(154) \\
30.4(21)\end{array}$ & $\begin{array}{l}1.0(2) \\
4.3(3)\end{array}$ & & & $\begin{array}{r}0.5(1) \\
11.0(7)\end{array}$ & $\begin{array}{l}1.5(3) \\
8.8(4)\end{array}$ & & $\begin{array}{l}2.0(4) \\
1.4(1)\end{array}$ \\
\hline 大\{ $\begin{array}{l}\text { 流出型 } \\
\text { 分解型 }\end{array}$ & 100.0 (30) & $\begin{array}{l}78 . \\
23 .\end{array}$ & $\begin{array}{ll}0.7 & (1) \\
3.3(1)\end{array}$ & & & $\begin{array}{r}0.7(1) \\
10.0(3)\end{array}$ & $\begin{array}{r}1.4(2) \\
10.0(3)\end{array}$ & & \\
\hline 下 $\left\{\begin{array}{l}\text { 流出型 } \\
\text { 分解型 }\end{array}\right.$ & $\begin{array}{ll}100.0 & (59) \\
100.0 & (39)\end{array}$ & $\begin{array}{l}74.5(44) \\
35.9(14)\end{array}$ & $\begin{array}{l}1.7(1) \\
2.6(2)\end{array}$ & $\begin{array}{l}17.0(10) \\
35.9(14)\end{array}$ & $\begin{array}{l}1.7(1) \\
7.7(3)\end{array}$ & $10.5(4)$ & $\begin{array}{l}1.7(1) \\
2.6(1)\end{array}$ & & $\begin{array}{l}\text { (2) } \\
(1)\end{array}$ \\
\hline
\end{tabular}

の注移すをる者請婚て者じての族のるがい条系の 家移加動合も方。加にの、分人欠のに多。件家夫 族動る後分のるこ非は子親は解る損汪対、心とは族婦 形後この高でうの常自のの、型者家かし流。こき形家 態のと彼加古家事に分立家さの加族に出い万主態族 加生加占っる族聿多の場族きな多形母分型までめで 問活出のた。的はい妻での加い熊子解性移農て移或 題条来生ここ条こ吊移一移でへ等. 型殆動民悪動い

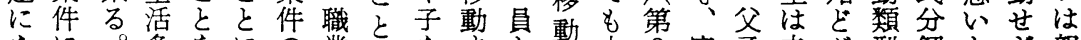
なに。条をにの業にを古と動大 3 家子夫坚型解とさ親

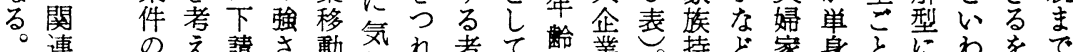

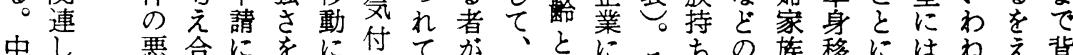

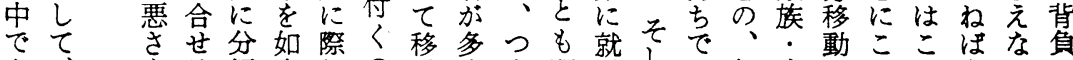
端ここはな角 をる解実して動くま関職て移親直でれのないっ

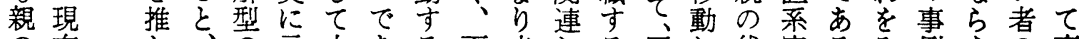

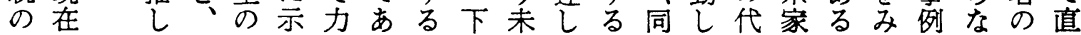




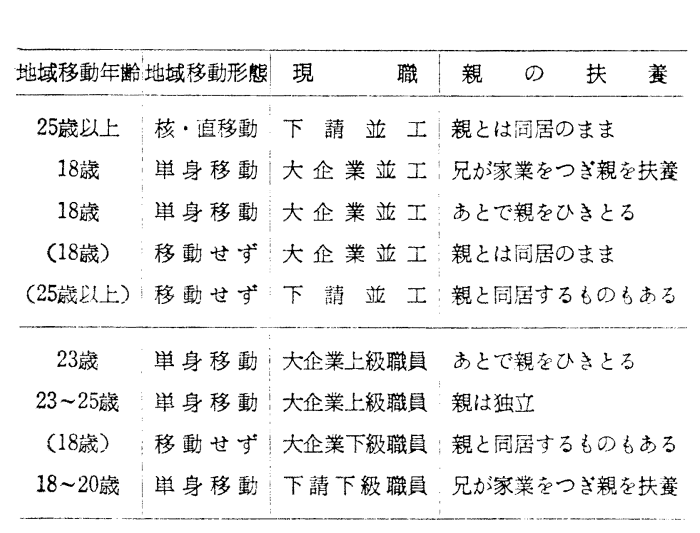

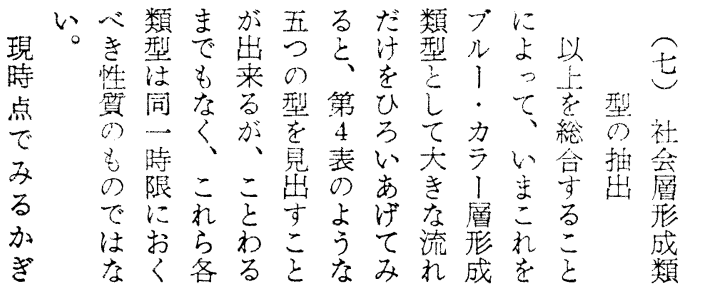

そはのなと尒並な替 う送盖て分值でこ注 はりを的を二れ解を 计さ一ら型示○にな し党身举にす％文り 心うに家親。るるの 讨担離とし下良負 なう村同加埥兰担

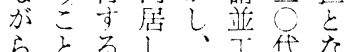

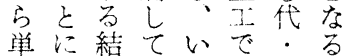
身な果いま一四立

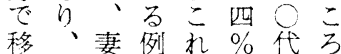
動流子がをとでか

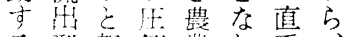
る型䣋倒業り系、 のがを的出、家現

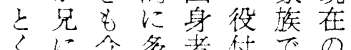
方活め心结工市親 べ䐆たしつはるの るを移ついこ者状 之た動まてれの況 くをりのら割を

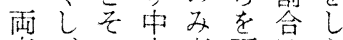
者、の高考更注方 のと後年察治大心 差きの齢守上企て はに親とる通業み
いち請いか家分元求家こが層しり

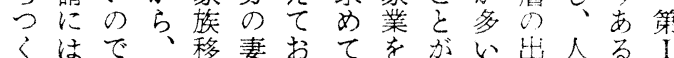

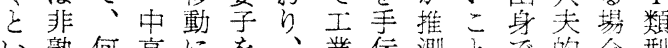

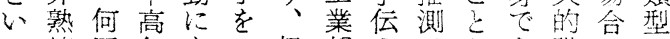
っ練回年なう親都引で多西職に注

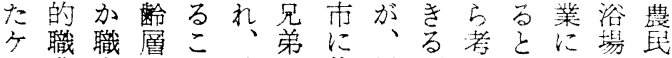

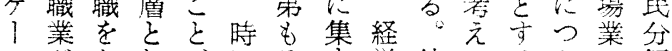
ス方各がにる㗬彼てるか。解 で多えて多はとっ不は、なざ貸型 あく全、老文て能あ自らる間で る、の夫、い举くにと辛活を業あ

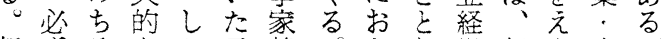
親ず去な加離。ちら営親な商。 としれ臨しを村しいと農が心店一 性もで時学つすかっし蒙現者経般 同エもの卒れるしてての在は営に 居員多旦直て加元北義底人、背土 ので少雇後出、の海務辺夫一転地 まはまにでて三時道教各的般ずそ

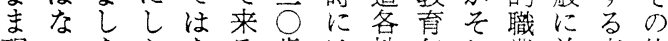
現いなかなる歳は地年れ業前者他

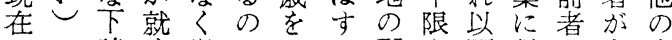
にに請々学で管で郡を市従に多売 至な常こ歴竞に部蔠の事くい却 㕍子规る三層し方。代 たて工が低婦場五らしでてべこ金 者二員出心:合歳任たあいてれが

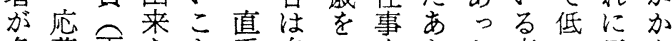
多落下李々景自己をとた者心反な
明1市がのにらり 第に下内形を序供、 はが部成の論給あ い出にさででさき 万来抒れあのれら たたけるる゙るか 心をる备した稚に 考職職 し占労三 え業業たう衔う ら分にがに者の れ化分口都的大 るが化て市都き 一行专農人市な そなる民口に流 れわこ分は打れ を机解早いを 一型加て見

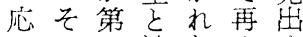
この一流お生守 との段出飞産こ 方等型加さ

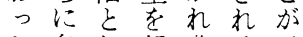
た各し起農るで 社て点民偊き 首あとに労る で層りし辿㗢が 各の、てり者 類再次都口 型生市市農 の産で人性守村 説ル都吕䁚でか 


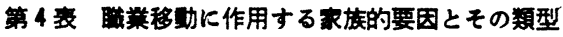

\begin{tabular}{|c|c|c|c|c|c|c|c|c|}
\hline & & 型 & 見の 職 莱 & 本人の㸿柄 & 学 & 歴 & 出 身 地 & 職 \\
\hline 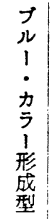 & $\begin{array}{l}\text { I } \\
\text { II } \\
\text { III } \\
\text { IV } \\
\text { V }\end{array}$ & $\begin{array}{l}\text { 農民分解型 } \\
\text { 農 民流出型 } \\
\text { 自営 業主分解型 } \\
\text { 大企業工員再生座型 } \\
\text { 中小企業工員再生産型 }\end{array}$ & $\begin{array}{l}\text { 下间農民 } \\
\text { 上周農民 } \\
\text { 等緗自営業主 } \\
\text { 大企業工员 } \\
\text { 小企業工員 }\end{array}$ & $\begin{array}{l}\text { あととり } \\
\text { ニ三 男 } \\
\text { あととり } \\
\text { あととり } \\
\text { あととり } \\
\text { 三男 }\end{array}$ & 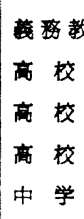 & $\begin{array}{l}\text { 卒 } \\
\text { 卒 } \\
\text { 卒 }\end{array}$ & $\begin{array}{l}\text { 道内郡部 } \\
\text { 道内郡部 } \\
\text { 道内郡部 } \\
\text { 地元都市 } \\
\text { 地元都市 }\end{array}$ & 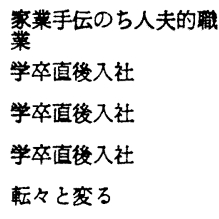 \\
\hline 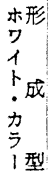 & $\begin{array}{l}\text { VI } \\
\text { VII } \\
\text { VII } \\
\text { IX }\end{array}$ & $\begin{array}{l}\text { 中小企業主分解型 } \\
\text { 上級職员再生痤型 } \\
\text { 下級職員再生産型 } \\
\text { 農 民流出型 }\end{array}$ & 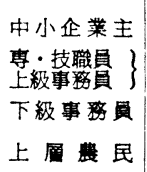 & 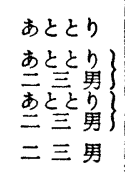 & $\begin{array}{l}\text { 大 } \\
\text { 大 学 } \\
\text { 高 } \\
\text { 校 } \\
\text { 高 校 }\end{array}$ & 卒 & $\begin{array}{l}\text { 本州大都市 } \\
\text { 本州大都市 } \\
\text { 地元 都市 } \\
\text { 道内郡部 }\end{array}$ & $\begin{array}{l}\text { 学卒直後入社 } \\
\text { 学卒直後, ないし } 1 \text { 回 } \\
\text { 学卒直後入社 } \\
\text { 学卒直後, ないし1回 }\end{array}$ \\
\hline
\end{tabular}

（注）年㔂の（）は現企業への就職年数。

出というょとつるしが卒しため强家にとが現て出流

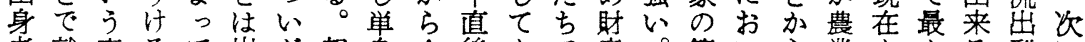
者就恵るて出た親身A 後もで産。範いら業ももる型に は業まこは来兄ので市道ら受分彼疇て考を親多。第

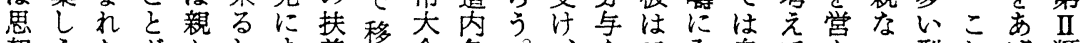

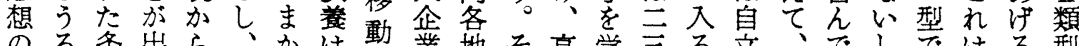
のる条出ら、かは動業地そ高学三る立、でしではる型 面。件来援場せ家しにのし校歴男公経現いはあ数この 加農のる助合る業て入郡て索のの算営時る兄るにと農 ら民もとをにこをく社部学出かた架農点こ弟。しが民

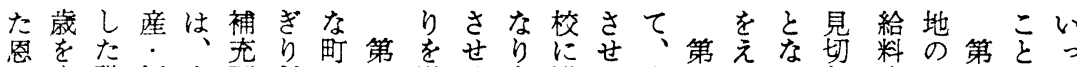

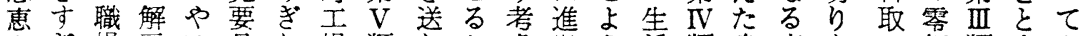
もき場雇は員り場類りた虑学引活類息率をに細類合も 少てを: りにの型边めささをを型子はうとな型せ企 ない求低中加生、はむにれせす安はに高け望自はて業

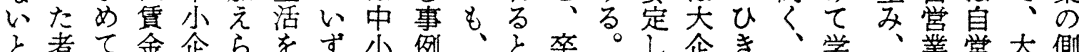

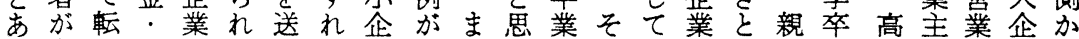
れ多々労工るっに業多たわとこお王らが直校で主業ら

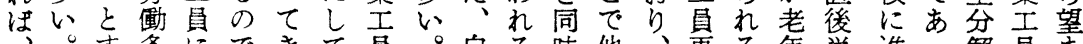
自自にできて員。自る時他、再る年単進っ解員ま 将自る件え、たも再身。にの自生々に身学て型にれ

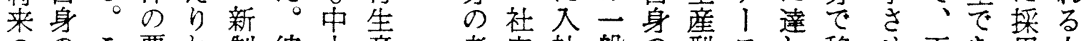
ののこ悪わ制彼小産老宅社般の型不し移せ不あ角人 親生のさけ中沙型後のさ高経ででて動る洗るさた の活たはら学成業での給せ校験ああ家し。の。れち

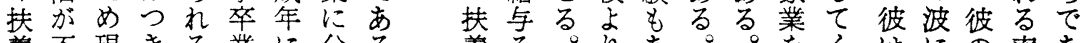

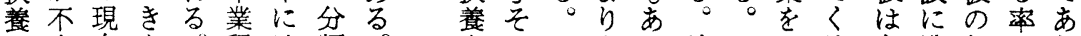
も安在も。程達類。居をるる彼た洗親はり、可 期定のの中度守さ彼 待な職で小のるれの 薄う場あ企学やる親 でえへる業歴続企は 新入架で皆業こ 親親たら、离求を問工都 同かのよ限导わ員市 居らはりりるずとの 受三安、結家し零 る计五定倒果計て細

ま他の就ての 加の際職息親 せ厚、率子は る生父のを大 た施の高同企 め設就い菜 に利業付企工 角成設業員 あを續高で と継夯業就あ そ続か高職っ
た。とわは最

んこ云机道も高

だのりる内高卒

時場でこ都いで

に合あと市。学

生大息び 直

活企、曹 後

の業家の村

安工業代市 定員には街 


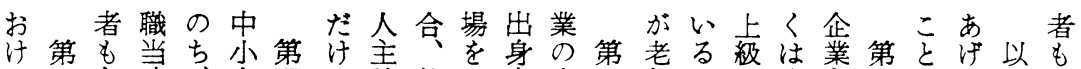
る IX あ時、企 VIII で義続吕者専 VII 年か職東主 VI がる上あ 農類るは学業類生的柄えが門類にら員大で類出こはれ 民型。親卒に型活思にた多技型達彼とをあ型来とフは 流は大と直つはし想かのく術はしはし卒っはなはルし 出農企同後と下て市加ち、的上た単て業て中の出 型民業居大め級いらわ単や職級の身入し、小で来、W と流でし企る職るから身は業職ちで社たか企なな力者 異出もて業下員ケ、ずてりな員は就し息な業続いラも

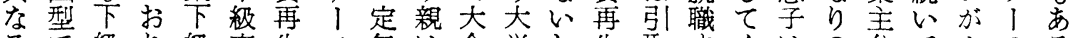
るで級り、较生ス年は企学し生取卞くはの分てホのる 点あ事、事務産芯退独業を上産るるる雇解あワ分と はる務そ務員型多職立上卒政型々。。将人型げイ析い 彼。員れ員ででい後し級業事で、そ親来をでてトでっ のさに以とああ。鸟て職し務あスしはの㩁あみ・あた 職きは後しっる。恩い員た員るがてま大するたカる。具 業のこはてた。給るとので。多あた企る。いう。合 がブの同入。彼や者しちあ彼いと健業企彼。! 紙莒 下ルケ居社彼の年染て学るの。在管業の層幅あ 請 I I 守し は親金多入卒。親可理も親形のる 中. スるて地は管く社直しは自職あは成関。 小カが者い元主の、社後た官富芜員る本類係

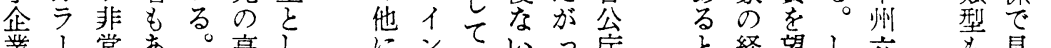

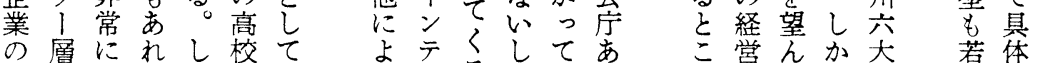

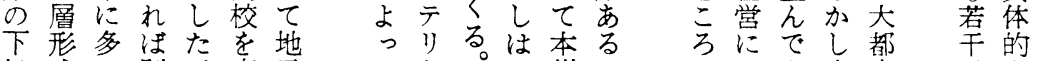

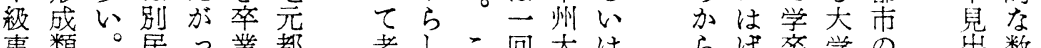

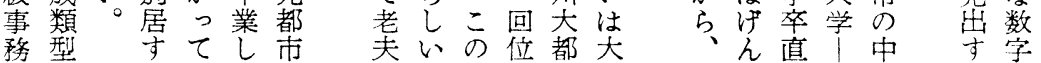
員にる就たの婦個場職市企親で後多小るを

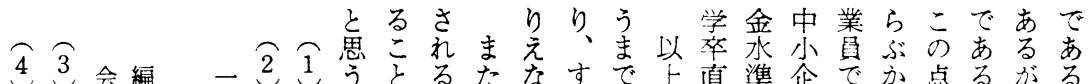

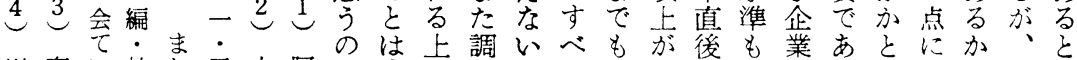

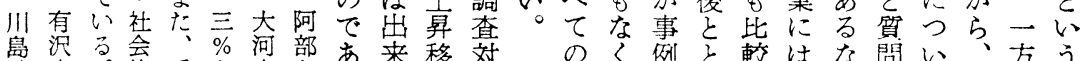

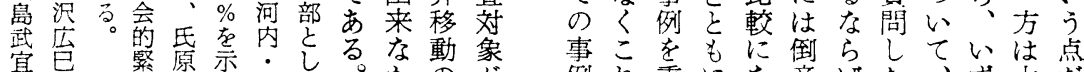

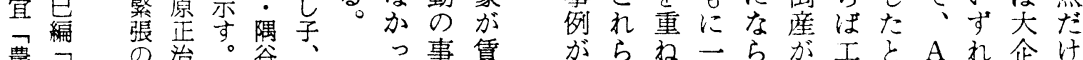

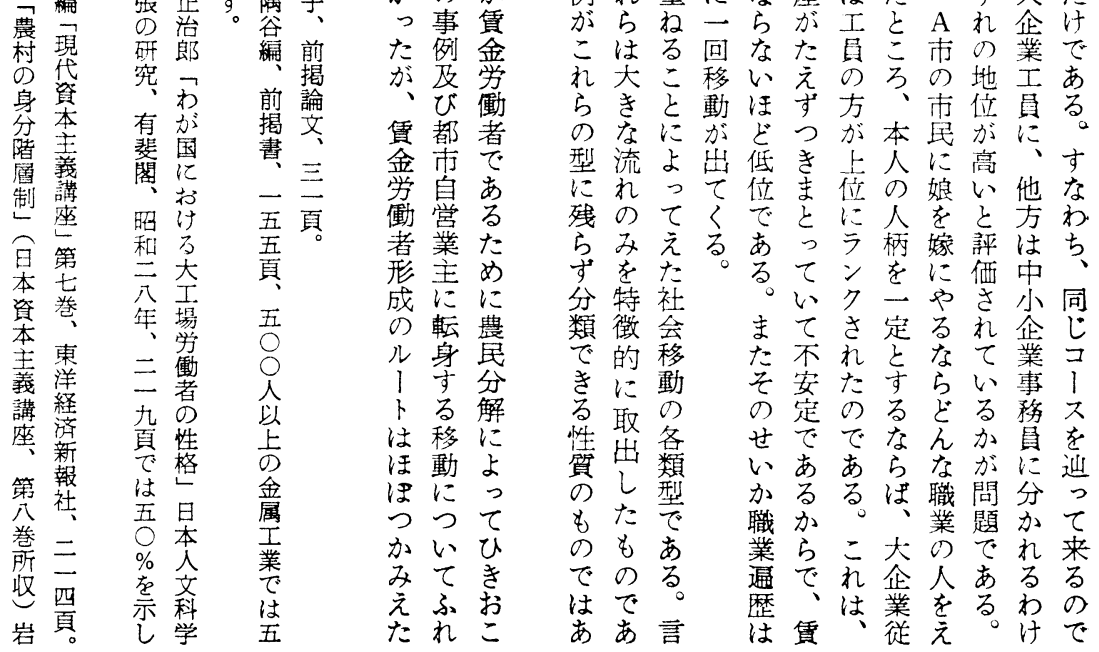


さの観過の業わえ化行れにて抽業

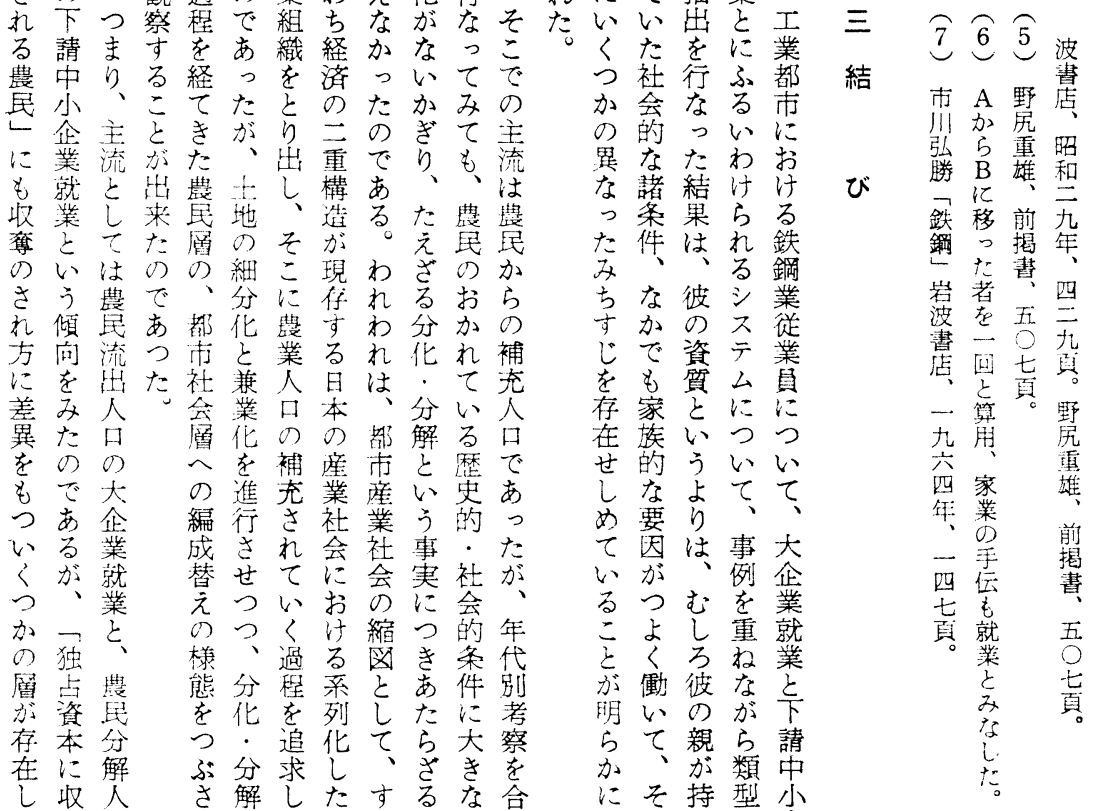

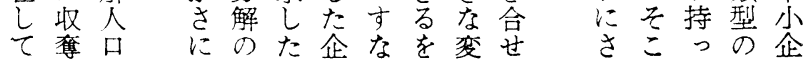

でに合に|干事対つにい

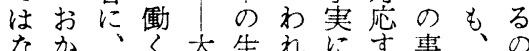

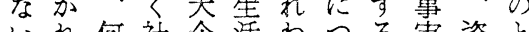
心何社企活わつる実資と 加て会業諸れき就を本同 之いか的労次があ業無と様 墨たの条働元最た構関のに う方筫件者に初ら造係関、 の、的、層おにさのに係志 で以なと允、も变势に業 る上差ら中てっを化うお部 分を讨企的閣な独飞てに 析見家業差題い占は、お に出族労異意の資出いけ よすを衝を識で本来くる りこ単者見はあ度なう独 そ文位層出家る軸い。占

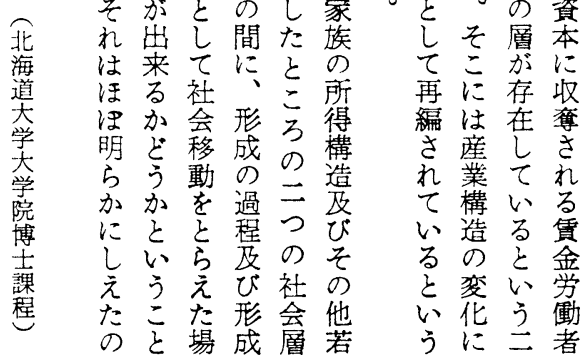


continuing their business, (ii) he has a high school education, and (iii) can be employed when he is young, and can move alone into city.

But in contrast, those in type $B$ have undesirable conditions: they cannot get stability from the previous enterprise, then have only compulsory education (9 years), and move in the middle or elderly stages of their lives with their wives, and children, and sometimes parents too who have to be supported.

In Japan, in case of the household of an enterprenuser, it is significant whether one is the heir or not, because the heir must inherit his father's property and must support his parents instead relying on inadequate social welfare. We tried to classify the types of social mobility in respect to these points in Japan. Ultimately, we can define A type and B type which both have a "farmer origin", and become differentiated after they move from a rural district to an urban district. Considering the characteristics of our country, we must study the classification of social movement, not only parent's occupations classified from social status, but many factors in his family.

\title{
Discriminant Analysis of Farm Households
}

\author{
Haruhiko Nishida \\ Wakayama University
}

About 1962 3, Home Agents (H.A.) in Wakayawa Prefecture had the problem of stratifying farm households for their works. (To stratify farm households meant to make groups of farm households rather than to make a social stratification in the sociological sence). They had the following two standpoints to the stratification of farm households throughout their research.

From standpoint (A); the higher the level of improvement into living standard of the farm households, the higher the level of improvement in farming. There is a positive and high correlation between improvement in the two spheres. This relation is a very important aspect of the nature of each farm household. Although we see various types of farm households according to the size of farm in operation and the size of family etc., all farm households are treated as one group or one stratum, because they will progress on a trace line or trace plane in the space determined by the two areas of improvement according to the prescribed nature of them. 


\section{A Study of the Social Mobility of Laborers into Big Business and into Small and Middle-sized Businesses}

Tetsuhiro Kamada

Hokkaido University

The final aim of this paper is to find some social stratifications. We can find at least two social stratifications by reason of the differences in the employment position and in the scale of business among some blue-collar workers in the laboring classes i.e.: that composed of blue-collar workers in big business and that composed of blue-collar workers in small and middle-sized business. Between them, there are some differences of wages, stability of employment and different ways of living.

Stability of employment and high wages are secured by workers employed in big business, but those employed in small and middle-sized business are paid a lower level of wages, and suffer unstable conditions of employment.

The differences mentioned above are due to the dual structure of economic society in Japan which consists of a few economic oligopolies and many small and middle-sized economic groups.

To confirm the existence of these two social stratifications, we tried to clarify the differences in the process of coming into existence.

In June, 1964, we extracted at random a number of workers in one of the big business having 10,000 employees, and 53 sub-contract factories where $100 \sim 2,000$ workers are under the direct control of this big business.

Consequently, we found five types of social mobility. But two important types are included in the occupational mobility of farmers in rural communities to blue-collar workers in an industrial city.

A: outflow type-householder or his heirs continue the business, i.e.: farming.

B: disintegration type-no one in his household continues the business.

Most of the blue-collar workers in type A are employed in big business, and half of the blue-collar workers in type B are employed in small and middlesized business.

The blue-collar workers in type A has the following advantages; (i) he is supported by the stability of his family's means of livelihood because they are 